NUREG-1492

\title{
Regulatory Analysis on Criteria for the Release of Patients Administered Radioactive Material
}

Draft Report for Comment

\section{U.S. Nuclear Regulatory Commission}

Office of Nuclear Regulatory Research

S. Schneider, S. A. McGuire/NRC

U. H. Behling, K. Behling, D. Goldin/S. C\&A., Inc.

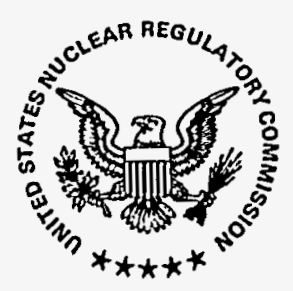




\section{AVAILABILITY NOTICE}

\section{Availability of Reference Materials Cited in NRC Publications}

Most documents cited in NRC publications will be available from one of the following sources:

1. The NRC Public Document Room, 2120 L Street, NW., Lower Level, Washington, DC 20555-0001

2. The Superintendent of Documents, U.S. Government Printing Office, Mail Stop SSOP, Washington, DC 20402-9328

3. The National Technical Information Service, Springfield, VA 22161

Although the listing that follows represents the majority of documents cited in NRC publications, it is not intended to be exhaustive.

Referenced documents available for inspection and copying for a fee from the NRC Public Document Room include NRC correspondence and internal NRC memoranda; NRC bulletins, circulars, information notices, inspection and investigation notices; licensee event reports; vendor reports and correspondence; Commission papers; and applicant and licensee documents and correspondence.

The following documents in the NUREG series are available for purchase from the GPO Sales Program: formal NRC staff and contractor reports, NRC-sponsored conference proceedings, international agreement reports, grant publications, and NRC booklets and brochures. Also available are regulatory guides, NRC regulations in the Code of Federal Regulations, and Nuclear Regulatory Commission Issuances.

Documents available from the National Technical Information Service include NUREG-series reports and technical reports prepared by other Federal agencies and reports prepared by the Atomic Energy Commission, forerunner agency to the Nuclear Regulatory Commission.

Documents available from public and special technical libraries include all open literature items, such as books, journal articles, and transactions. Federal Register notices, Federal and State legislation, and congressional reports can usually be obtained from these libraries.

Documents such as theses, dissertations, foreign reports and translations, and non-NRC conference proceedings are available for purchase from the organization sponsoring the publication cited.

Single copies of NRC draft reports are available free, to the extent of supply, upon written request to the Office of Administration, Distribution and Mail Services Section, U.S. Nuclear Regulatory Commission, Washington, DC 20555-0001.

Copies of industry codes and standards used in a substantive manner in the NRC regulatory process are maintained at the NRC Library, 7920 Norfolk Avenue, Bethesda, Maryland, for use by the public. Codes and standards are usually copyrighted and may be purchased from the originating organization or, if they are American National Standards, from the American National Standards Institute, 1430 Broadway, New York, NY 10018. 


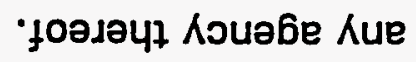

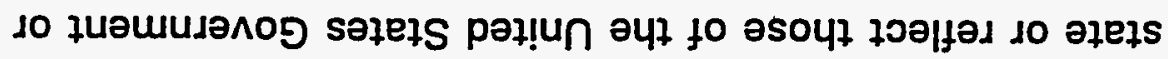
A!ldessarau zou op u!ajay passajdxa sjoulne to suo!u!do

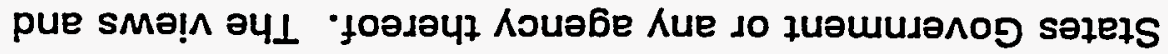

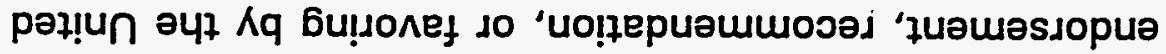

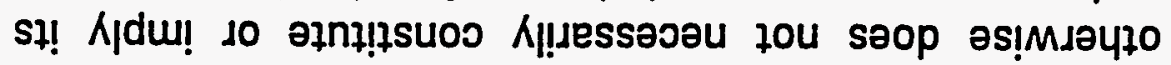

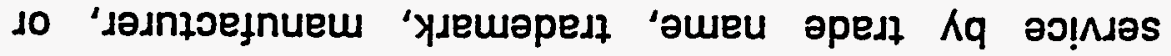

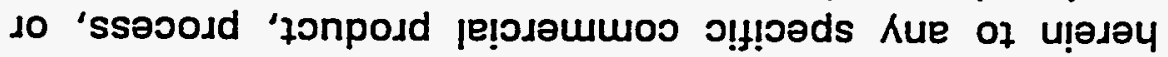

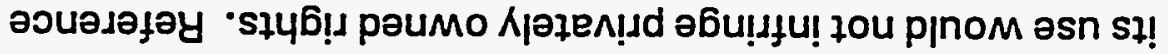

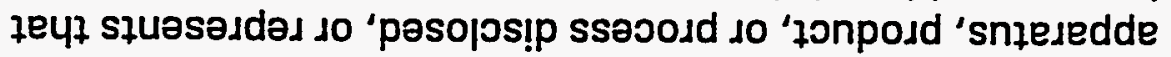

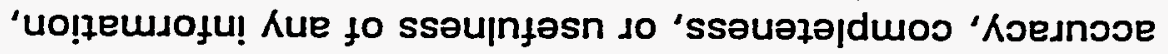

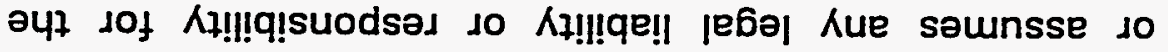

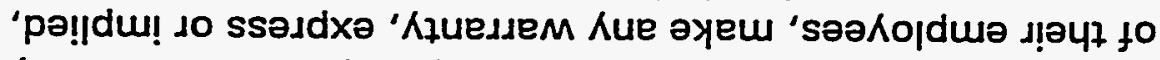

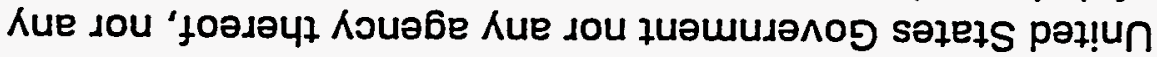
әц7 dә4ł!

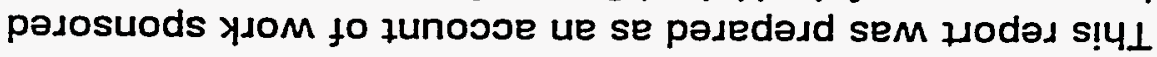

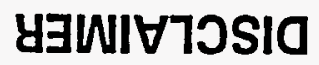




\section{DISCLAIMER}

Portions of this document may be illegible in electronic image products. Images are produced from the best available original document. 


\title{
Regulatory Analysis on Criteria for the Release of Patients Administered Radioactive Material
}

\author{
Draft Report for Comment
}

Manuscript Completed: March 1994

Date Published: May 1994

S. Schneider, S. A. McGuire

U. H. Behling*, K. Behling*, D. Goldin*

Division of Regulatory Applications Office of Nuclear Regulatory Research U.S. Nuclear Regulatory Commission Washington, DC 20555-0001

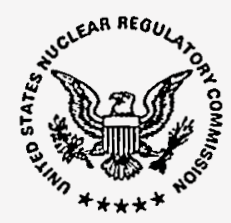

*S. Cohen \& Associates, Inc. 1355 Beverly Road, Suite 250 McLean, VA 22101 


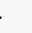




\begin{abstract}
The Nuclear Regulatory Commission (NRC) has received two petitions to amend its regulations in 10 CFR Parts 20 and 35 as they apply to doses received by members of the public exposed to patients released from a hospital after they have been administered radioactive material. While the two petitions are not identical, they both request that the NRC establish a dose limit of 5 millisieverts $(0.5 \mathrm{rem})$ per year for individuals exposed to patients who have been administered radioactive materials. This Regulatory Analysis evaluates three alternatives. Alternative 1 is for the NRC to amend its patient release criteria in 10 CFR 35.75 to use the more stringent dose limit of 1 millisievert $(0.1 \mathrm{rem})$ per year in 10 CFR 20.1301(a) for its patient release criteria. Alternative 2 is for the NRC to continue using the existing patient release criteria in 10 CFR 35.75 of 1,110 megabecquerels ( 30 millicuries) of activity or a dose rate at one meter from the patient of 0.05 millisievert ( 5 millirems) per hour. Alternative 3 is for the NRC to amend the patient release criteria in 10 CFR 35.75 to specify a dose

limit of 5 millisieverts ( $0.5 \mathrm{rem})$ for patient release. The evaluation demonstrates that, except for a few diagnostic procedures using iodine-131, diagnostic procedures are unaffected by the choice of alternative. Only some therapeutic administrations of radioactive material could be affected by the choice of alternative. The evaluation indicates that Alternative 1 would cause a prohibitively large increase in the national health care cost from retaining patients in a hospital longer and would cause significant personal and psychological costs to patients and their families. The choice of Alternatives 2 or 3 would affect only thyroid cancer patients treated with iodine-131. For those patients, Alternative 3 would result in less hospitalization than Alternative 2. Alternative 3 has a potential decrease in national health care cost of $\$ 30,000,000$ per year but would increase the potential collective dose from released therapy patients by about 2,700 person-rem per year, mainly to family members. Alternative 3 would also have personal and psychological benefits for the patients and their families.
\end{abstract}




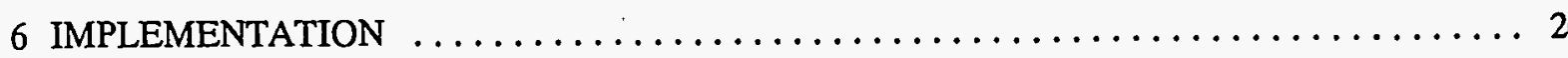

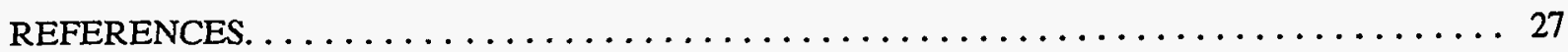

Tables

4.1 Estimated Number of Diagnostic Radiopharmaceutical Procedures Performed in the U.S.

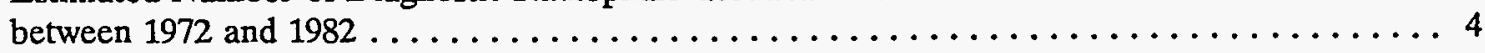

4.2 Estimated Radiopharmaceutical Use for Diagnostic Procedures in the U.S. in 1993 . . . . . 5

4.3 Age and Sex Distribution of Patients Having Nuclear Medicine Examinations . . . . . . . 6

4.4 Radiopharmaceuticals for Radiotherapy $\ldots \ldots \ldots \ldots \ldots \ldots \ldots \ldots \ldots \ldots \ldots \ldots$

4.5 Data Relevant to Radionuclides Used in Brachytherapy Permanent Implants . . . . . . . . 11

4.6 Number of Annual Therapeutic Administrations in the U. S. (significant gamma-emitting

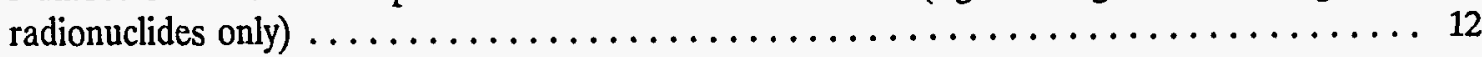

4.7 Specific Gamma-Ray Constants and Dose Rates at 1 Meter $\ldots \ldots \ldots \ldots \ldots \ldots \ldots \ldots$

4.8 Screening Calculation of Total Gamma Dose to Decay at 1 Meter Due to Administrations of Radioactive Materials . . . . . . . . . . . . . . . . . . . . . . . . . . . 14

4.9 Family Doses from Patients Treated for Thyroid Carcinoma $\ldots \ldots \ldots \ldots \ldots \ldots \ldots$

4.10 Parameters for Use in Estimating Iodine-131 Retention $\ldots \ldots \ldots \ldots \ldots \ldots \ldots \ldots \ldots$

4.11 Maximum Likely Doses to Exposed Individuals from Therapeutic Procedures . . . . . . . . 20

4.12 Estimates of Collective Dose from Therapeutic Radioiodine Procedures for Alternative 1:

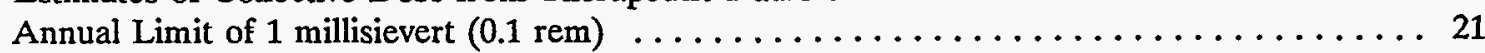

4.13 Estimates of Collective Dose from Therapeutic Radioiodine Procedures for Alternative 2: Limit of 1,110 megabecquerels (30 millicuries) or 0.05 millisievert $(5$ millirems $) / \mathrm{hr} \ldots \ldots \ldots 21$

4.14 Estimates of Collective Dose from Therapeutic Radioiodine Procedures for Alternative 3:

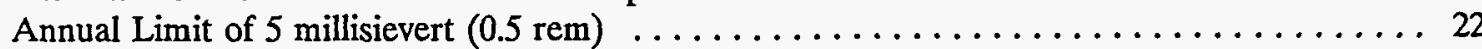

4.15 Duration of Retention per Therapeutic Procedure (to the nearest day) $\ldots \ldots \ldots \ldots \ldots$

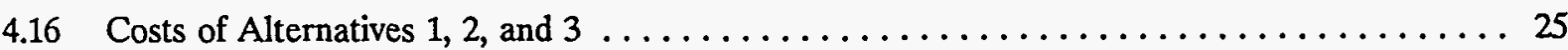




\section{CONTENTS}

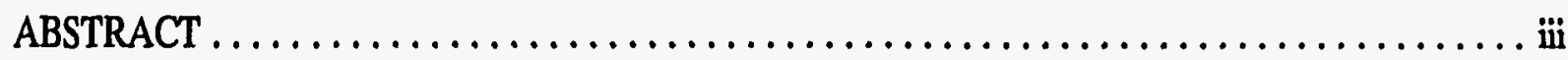

ACKNOWLEDGEMENTS $\ldots \ldots \ldots \ldots \ldots \ldots \ldots \ldots \ldots \ldots \ldots \ldots \ldots \ldots \ldots \ldots$ vii

1 STATEMENT OF THE PROBLEM $\ldots \ldots \ldots \ldots \ldots \ldots \ldots \ldots \ldots \ldots \ldots \ldots \ldots \ldots$

2 OBJECTIVES OF THE RULEMAKING $\ldots \ldots \ldots \ldots \ldots \ldots \ldots \ldots \ldots \ldots \ldots \ldots \ldots$

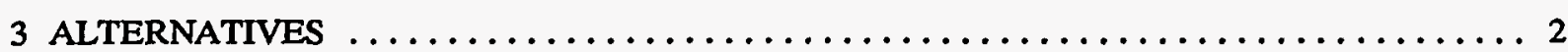

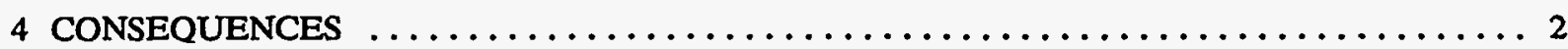

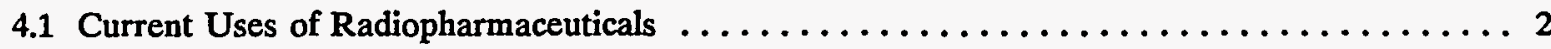

4.1.1 Diagnostic Uses of Radiopharmaceuticals $\ldots \ldots \ldots \ldots \ldots \ldots \ldots \ldots \ldots \ldots \ldots \ldots$

4.1.2 Therapeutic Administrations . . . . . . . . . . . . . . . . . . . . . . . 4

4.1.2.1 Radiopharmaceuticals Used in Therapy .................... 6

4.1.2.2 Radioactive Materials Used in Permanent Implants (Brachytherapy) . . . . . . 10

4.1.2.3 Summary of Therapeutic Administrations ................... 11

4.2 Assessment of Doses to Individuals Exposed to Patients Administered Radioactive

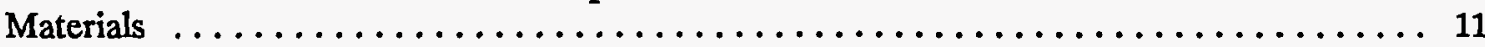

4.2.1 Methodology for Calculating Direct Gamma Dose $\ldots \ldots \ldots \ldots \ldots \ldots \ldots \ldots \ldots$

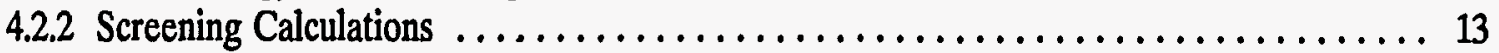

4.2.3 Estimate of Maximum Likely Dose to Individuals Exposed to Patients $\ldots \ldots \ldots \ldots \ldots$

4.2.3.1 Exposure Factor . . . . . . . . . . . . . . . . . . 15

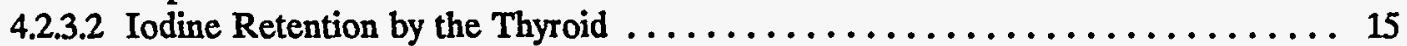

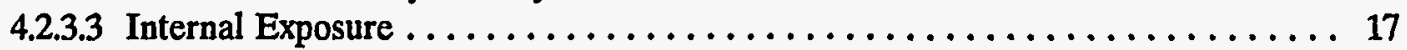

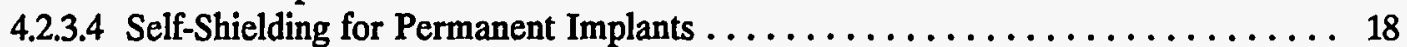

4.2.3.5 Summary of Maximum Likely Doses . . . . . . . . . . . . . . 19

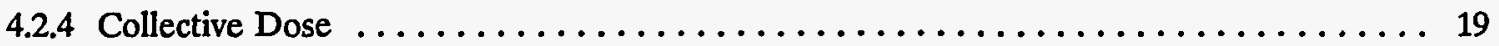

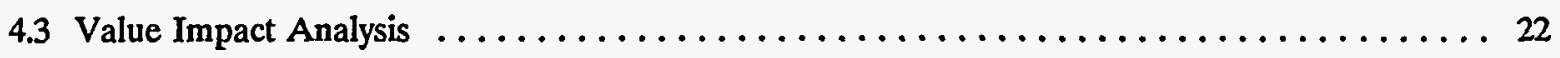

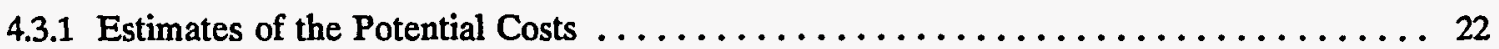

4.3.1.1 Estimates of the Direct Costs of Patient Retention $\ldots \ldots \ldots \ldots \ldots \ldots \ldots 22$

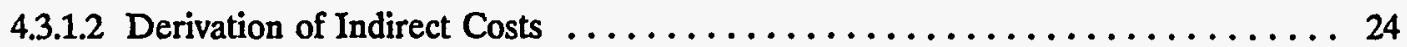

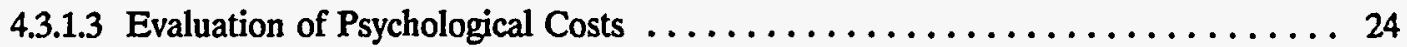

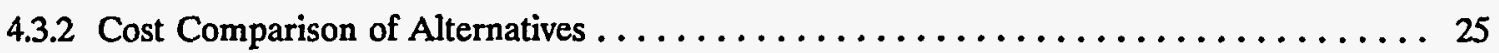

4.4 Evaluation Of The Alternatives With Respect to Accepted Radiation Protection

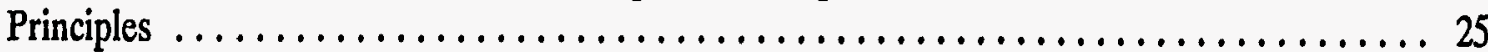

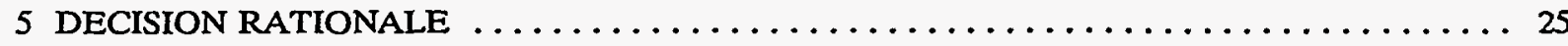




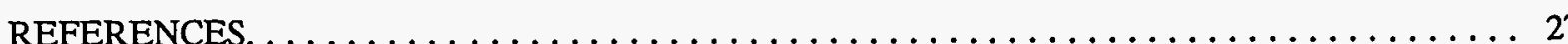

Tables

4.1 Estimated Number of Diagnostic Radiopharmaceutical Procedures Performed in the U.S.

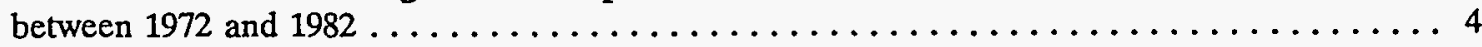

4.2 Estimated Radiopharmaceutical Use for Diagnostic Procedures in the U.S. in $1993 \ldots \ldots$

4.3 Age and Sex Distribution of Patients Having Nuclear Medicine Examinations . . . . . . . 6

4.4 Radiopharmaceuticals for Radiotherapy $\ldots \ldots \ldots \ldots \ldots \ldots \ldots \ldots \ldots \ldots \ldots$

4.5 Data Relevant to Radionuclides Used in Brachytherapy Permanent Implants . . . . . . . 11

4.6 Number of Annual Therapeutic Administrations in the U. S. (significant gamma-emitting

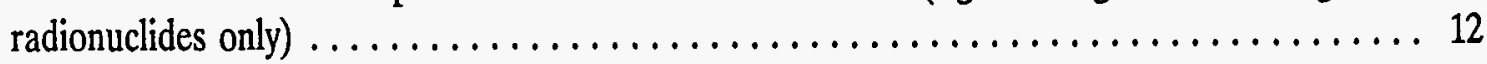

4.7 Specific Gamma-Ray Constants and Dose Rates at 1 Meter $\ldots \ldots \ldots \ldots \ldots \ldots$

4.8 Screening Calculation of Total Gamma Dose to Decay at 1 Meter Due to Administrations of Radioactive Materials . . . . . . . . . . . . . . . . . . . . . 14

4.9 Family Doses from Patients Treated for Thyroid Carcinoma $\ldots \ldots \ldots \ldots \ldots \ldots \ldots$

4.10 Parameters for Use in Estimating Iodine-131 Retention $\ldots \ldots \ldots \ldots \ldots \ldots \ldots \ldots$

4.11 Maximum Likely Doses to Exposed Individuals from Therapeutic Procedures . . . . . . . . 20

4.12 Estimates of Collective Dose from Therapeutic Radioiodine Procedures for Alternative 1:

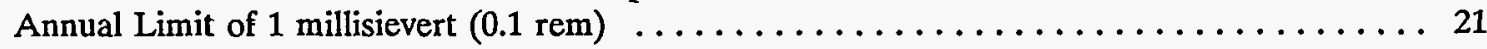

4.13 Estimates of Collective Dose from Therapeutic Radioiodine Procedures for Alternative 2: Limit of 1,110 megabecquerels (30 millicuries) or 0.05 millisievert $(5$ millirems $) / \mathrm{hr} \ldots \ldots 21$

4.14 Estimates of Collective Dose from Therapeutic Radioiodine Procedures for Alternative 3:

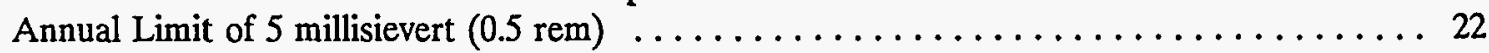

4.15 Duration of Retention per Therapeutic Procedure (to the nearest day) $\ldots \ldots \ldots \ldots \ldots$

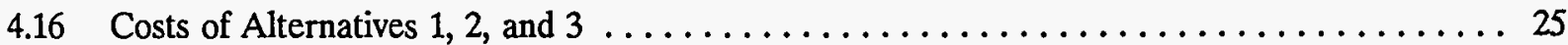




\section{ACKNOWLEDGEMENTS}

Much of the statistical and technical information required for this analysis is not available in the open literature. In such instances, information was obtained directly from technical experts. The following individuals are acknowledged for their cooperation and contribution of technical information and data.

R. Atcher, $\mathrm{PhD}$, Staff Consultant to the Society of Nuclear Medicine, Argonne National Laboratory, Argonne, IL

D. Flynn, M.D., Massachusetts General Hospital (NRC Advisory Committee on Medical Use of Isotopes), Boston, MA

W.R. Hendee, $\mathrm{PhD}$, Dean of Research, Medical College of Wisconsin, Milwaukee, WI

C. Jacobs, President, Theragenics, Norcross, GA

F.A. Mettler, M.D., Department of Radiology, University of New Mexico, School of Medicine, Albuquerque, NM

K. L. Miller, CHP, Professor of Radiology and Director, Division of Health Physics, Milton Hershey Medical Center, Hershey, PA
R. Nath, $\mathrm{PhD}$, Professor of Yale University, School of Medicine, and President of the American Association of Nuclear Physics, New Haven, CT

M.P. Nunno, $\mathrm{PhD}, \mathrm{CHP}$, Cooper Hospital, University Medical Center, Camden, NJ

P. Paras, $\mathrm{PhD}$, Food and Drug Administration, Center for Devices and Radiology Health, Rockville, MD

M. Polycove, M.D., Visiting Medical Fellow, U.S. Nuclear Regulatory Commission, Rockville, MD

M. Rosenstein, $\mathrm{PhD}$, Food and Drug Administration, Center for Devices and Radiology Health, Rockville, MD

J. St.Germain, Radiation Safety Officer, Memorial Sloan Kettering, New York City, NY

D. Steidley, $\mathrm{PhD}, \mathrm{CHP}$, Medical Health Physicist, Department of Oncology, St. Barnabas Medical Center, Livingston, NJ

K. Suphanpharian, $\mathrm{PhD}$, President, Best Industries, Springfield, VA 


\section{STATEMENT OF THE PROBLEM}

Each year in the U.S., radioactive pharmaceuticals or radioactive implants are administered to roughly 8 to 9 million patients for the diagnosis or treatment of disease. These people can expose others around them to radiation until the radioactive material has been excreted from their bodies or has decayed away.

NRC's patient release criteria in 10 CFR 35.75, "Release of patients containing radiopharmaceuticals or permanent implants," are as follows: "(a) A licensee may not authorize release from confinement for medical care any patient administered a radiopharmaceutical until either: (1) The measured dose rate from the patient is less than 5 millirems per hour at a distance of 1 meter; or (2) The activity in the patient is less than 30 millicuries; (b) A licensee may authorize the release of a patient administered a permanent implant only if "the measured dose rate is less than 5 millirems per hour at a distance of 1 meter."

On May 21, 1991, the NRC published a final rule that amended 10 CFR Part 20, "Standards for Protection Against Radiation" (56 FR 23360). The rule contained limits on the radiation dose for members of the public in 10 CFR 20.1301. However, when 10 CFR Part 20 was issued, there was no discussion in the supplemental information on whether or how the provisions of 10 CFR 20.1301 were intended to apply to the release of patients, thereby creating the need to address this issue.

Because some licensees were uncertain what effect the revised 10 CFR Part 20 would have on patient release criteria, two petitions for rulemaking were received on this issue. The first petition, submitted by Dr. Carol S. Marcus (PRM-20-20, 56 FR 26945), requests that the NRC:

(1) Raise the annual radiation dose limit in 10 CFR 20.1301(a) for individuals exposed to radiation from patients receiving radiopharmaceuticals for diagnosis or therapy from 1 millisievert $(0.1 \mathrm{rem})$ to 5 millisieverts (0.5 rem).
(2) Amend 10 CFR 35.75(a)(2) to retain the 1,110-megabecquerel (30-millicurie) limit for iodine-131 (I-131), but provide an activity limit for other radionuclides consistent with the calculational methodology employed in the National Council on Radiation Protection and Measurements (NCRP) Report No. 37, "Precautions in the Management of Patients Who Have Received Therapeutic Amounts of Radionuclides" (NCRP70).

(3) Delete 10 CFR 20.1301(d) which requires licensees to comply with provisions of EPA's environmental regulations in 40 CFR Part 190 in addition to complying with the requirements of 10 CFR Part 20.

The second petition, submitted by the American College of Nuclear Medicine (ACNM) (PRM-35-10, 57 FR 8282, as revised by PRM-35-10A, 57 FR 21043), requests that the NRC:

(1) Adopt a dose limit of 5 millisieverts $(0.5 \mathrm{rem})$ for individuals exposed to patients who have been administered radiopharmaceuticals.

(2) Permit licensees to authorize release from hospitalization any patient administered a radiopharmaceutical even if the activity in the patient is greater than 1,110 megabecquerels (30 millicuries) by defining "confinement" to include confinement in a private residence.

Since the petitions submitted by Dr. Marcus and the ACNM both address the patient release criteria in $10 \mathrm{CFR} 35.75$, the NRC has decided to resolve these petitions in a single rulemaking.

\section{OBJECTIVES OF THE RULEMAKING}

The objective of this rulemaking is to respond to the two petitions for rulemaking by amending, as deemed appropriate, the patient release criteria in 10 CFR 35.75 . 


\section{ALTERNATIVES}

As the petitions and the public comments that were submitted to the Commission on the petitions make clear, some licensees were uncertain about whether dose limits imposed by 10 CFR 20.1301(a) or the patient release criteria established by 10 CFR 35.75 govern patient release. In the Commission's view, 10 CFR 35.75 governs patient release as explained in the Notice of Proposed Rulemaking associated with this analysis. The public comments received on the two petitions also make it clear that the majority of commenters favor an annual dose limit of 5 millisieverts $(0.5 \mathrm{rem})$. Given that 10 CFR Part 35 is deemed to be the controlling regulation, the Commission is faced with the decision regarding the regulatory approach to be pursued in $10 \mathrm{CFR}$ 35.75. To evaluate the issues raised by the petitioners and those who commented on the requests made by the petitioners, the NRC has determined that the following alternatives should be evaluated:

- Alternative 1: 1 millisievert $(0.1 \mathrm{rem}) / \mathrm{yr}$ total effective dose equivalent

In this alternative, a 1 millisievert $(0.1 \mathrm{rem})$ per year dose limit is evaluated as the controlling criteria for determining when a patient may be released from the licensee's control.

- Alternative 2: $<1,110$ megabecquerels (30 millicuries) or $<0.05$ millisievert (5 millirems)/hr at 1 meter

In this alternative, the current patient release criteria in 10 CFR 35.75 is evaluated as the controlling requirement for determining when a patient may be released from the licensee's control.

- Alternative 3: 5 millisieverts $(0.5 \mathrm{rem}) / \mathrm{yr}$ total effective dose equivalent)

This alternative evaluates a dose limit of 5 millisieverts $(0.5 \mathrm{rem})$ per year to an individual exposed to a patient as the limiting factor for determining when a patient may be released from the licensee's control.

\section{CONSEQUENCES}

To evaluate the impacts of the three alternatives, it is necessary to determine which current procedures involving the administration of radiopharmaceuticals or permanent implants might be affected by the imposition of a 1-millisievert (0.1-rem) total effective dose equivalent per year dose limit for individuals exposed to released patients. For convenience, procedures involving the administration of radioactive materials to patients may be classified as: 1) diagnostic procedures involving administration of radiopharmaceuticals to obtain information about normal and pathological processes in the patient; or, 2) therapeutic procedures involving administration of radiopharmaceuticals or implantation of a radioactive source to destroy diseased tissue in the patient.

\subsection{Current Uses of Radiopharmaceuticals}

Radiopharmaceuticals can be defined as "drugs" that are radioactive and because of this property are used to (1) obtain information about normal and pathological processes in human organisms or (2) destroy tissue. The first group of compounds represents diagnostic and the latter therapeutic radiopharmaceuticals. Although radiopharmaceuticals may be classified as drugs, it should be noted that neither the diagnostic nor therapeutic radiopharmaceuticals are given for the purpose of exerting a pharmacological action.

Radiopharmaceuticals are generated from two sources: nuclear reactors and accelerators. Nuclear reactors can produce radionuclides through neutron capture reactions (e.g., $(\mathrm{n}, \gamma)$, $(\mathrm{n}, \mathrm{p})$, and $(\mathrm{n}, \alpha)$, as well as by nuclear fission $(\mathrm{n}, \mathrm{f})$ ). Other radiopharmaceuticals are accelerator produced, in which a highly pure target material is bombarded with $\mathrm{p}$, $\mathrm{d}$, or $\alpha$ particles. Many have relatively short half-lives. Some radiopharmaceuticals may be produced by either reactor or accelerator (e.g., palladium-103, iodine-125). The choice in production method is dictated by cost considerations and vendor access to a high neutron flux reactor facility. While most iodine- 125 has in the past and continues to be 
produced by reactors, the production of palladium-103 has shifted from reactor to accelerator (personal communication, C. Jacobs, August 1993).

\subsubsection{Diagnostic Uses of Radiopharmaceuticals}

Estimates regarding the frequency and total number of diagnostic nuclear medicine procedures have been reported over the years in several studies reviewed and analyzed by Mettler, et al. (ME85). Among the earliest data reported was a study supported by the American College of Radiology (ACR75), which reflects data collected in 1972 by J. Lloyd Johnson Associates. Additional data for the years 1973 and 1975 were obtained in a similar fashion and also published in the American College of Radiology Manpower Survey (ACR82).

In 1975, the Bureau of Radiological Health (BRH; now the Center for Medical Devices and Radiological Health, CDRH) of the U.S. Food and Drug Administration initiated a pilot study that surveyed information reported by six hospitals to the Medically Oriented Data System (MODS). This project was later expanded to include 26 stratified hospitals that provided data for 1977 and 1978 (FDA85).

Comprehensive data on 1980 diagnostic imaging procedures were obtained by J. Lloyd Johnson Associates by mail questionnaire using a stratified random sample of general hospitals and selected office practices in the U.S. (JO83). The sample included 6,109 hospitals and was estimated to reflect about 90 percent of the total diagnostic imaging examinations. Additional studies were conducted by the BRH for the years 1980, 1981, and 1982. The hospital-based survey was called the Radiation Experience Data (RED 1 and RED 2 studies) (ME85). The RED 1 study examined the computer billing records of 81 hospitals. Data for the subsequent RED 2 study reflect information obtained by mail survey from 500 hospitals.

Data for 1982 were also provided by Parker, et al. (PA84) in which a randomized sample of 10 percent of the U.S. hospitals was surveyed. Although his survey was specifically directed to thyroid examinations, survey data also provided estimates of total examinations.
All of the studies mentioned above are summarized in Table 4.1 and represent hospital data only. However, the exclusion of non-hospital facilities should not significantly affect the accuracy of estimates since less than 1 percent of all nuclear medicine procedures are performed outside hospitals (JO83). Inspection of Table 4.1 reveals several important trends. While the total number of diagnostic procedures has shown a general increase, the number of specific procedures has in some cases dramatically increased or decreased. By 1982, there were fewer radionuclide brain imaging examinations than in 1972, undoubtedly due to replacement by computerized tomography (ME85). For the same period, liver imaging increased tenfold. The largest percent increase involves cardiovascular imaging, which increased from an estimated 25,000 procedures in 1972 to about 950,000 in 1982 . Other procedures such as renal, lung, and tumor imaging have experienced only modest increases in numbers.

A search of the open literature revualed no recent comprehensive studies to assess more current U.S. use of radiopharmaceuticals. It is generally thought, however, that the frequency and usage of radiopharmaceuticals have stabilized because of the competing and/or complementary technologies of computerized tomography, magnetic resonance imaging, and gray-scale ultrasound (personal communication, F. A. Mettler, March 1993). For this report, the most recent RED 2 frequency distribution and the cumulative frequency of 32 diagnostic nuclear medicine procedures per one-thousand population will be used to estimate current usage. Table 4.2 provides frequency estimates of diagnostic procedures adjusted to reflect the 1993 U.S. population, which is projected at $256,466,000$ by the U.S. Bureau of the Census.

The identity, chemical form, and average quantity of radionuclides used for diagnostic in-vivo procedures are cited in Table 4.2 and reflect values cited by Mettler (ME85). It can be assumed that the average quantity per examination has not significantly changed since the time of original publication (personal communication, F. A. Mettler, March 1993).

As the results in Table 4.2 indicate, there are approximately 8.2 million diagnostic examinations employing radiopharmaceuticals performed annually in the U.S. Of these, more than 85 percent 
Table 4.1 Estimated Number of Diagnostic Radiopharmaceutical Procedures Performed in the U.S. between 1972 and 1982

\begin{tabular}{|c|c|c|c|c|c|c|c|c|c|}
\hline \multirow[b]{4}{*}{$\begin{array}{l}\text { Examination } \\
\text { Type }\end{array}$} & \multicolumn{9}{|c|}{ Year } \\
\hline & 1972 & 1973 & 1975 & 1978 & 1980 & 1980 & 1981 & 1982 & 1982 \\
\hline & \multicolumn{9}{|c|}{$\underline{\text { Source }}$} \\
\hline & ACR & ACR & ACR & MODS & Johnson & RED 1 & RED 2 & RED 2 & Parker \\
\hline Brain & $1260^{(1)}$ & 1510 & 2120 & 1546 & 870 & 1176 & 1038 & 812 & --- \\
\hline Hepatobiliary & 26 & --- & --- & --- & -- & --- & 109 & 179 & --- \\
\hline Liver & 455 & 535 & 676 & 1302 & 1180 & 1399 & 1445 & 1424 & -- \\
\hline Bone & 81 & 125 & 220 & 1160 & 1270 & 1307 & 1613 & 1811 & -- \\
\hline Respiratory & 332 & 417 & 597 & 1053 & 830 & 898 & 1095 & 1191 & --- \\
\hline Thyroid & 356 & 460 & 627 & 699 & 650 & 506 & 664 & 677 & 533 \\
\hline Urinary & 108 & 122 & 154 & 205 & 200 & 164 & 402 & 236 & -- \\
\hline Tumor & 10 & 14 & 22 & 166 & 130 & -- & 125 & 121 & -- \\
\hline Cardiovascular & 25 & 33 & 49 & 160 & 580 & 558 & 708 & 950 & -- \\
\hline Other & 686 & 294 & 338 & 120 & 120 & 368 & -- & -- & -- \\
\hline Total & 3339 & 3510 & 4803 & 6411 & 5830 & 6374 & 7199 & 7401 & 7690 \\
\hline & $(16)^{(2)}$ & (17) & (22) & (29) & (26) & (28) & (31) & (32) & (33) \\
\hline
\end{tabular}

Source: ME85.

(1) Numbers not in parenthesis indicate number of examinations $\times 1,000$.

(2) Numbers in parenthesis indicate number of examinations/1,000 population.

use technetium-99m (Tc-99m) as the label, about 5 percent use xenon-133 (Xe-133), about 5 percent use thallium-201 (Tl-201), about 3 percent use iodine-131 or iodine-123 (I-123), and about 2 percent use gallium-67 (Ga-67).

\section{Age and Sex Distribution of Patients}

The age and sex distribution of the U.S. population that underwent nuclear medicine examinations in 1980 is shown in Table 4.3. For the period of observation, more than three-fourths of all nuclear medicine examinations were performed on persons over the age of 45 ; nearly 40 percent of these patients were 64 years and older. With the exception of the youngest age category, the percentage of females exceeded males.

\subsubsection{Therapeutic Administrations}

Therapeutic use of radioactive materials involves two distinct approaches. The first involves the oral, intravenous, or intracavity administration of a radiopharmaceutical that may subsequently be distributed, concentrated, retained, and eliminated by physical, chemical, and metabolic actions occurring within the body. The second approach involves the implantation of radioactive sources (i.e., seeds) directly into a solid tumor. While both temporary and permanent implants are performed, all patients receiving temporary implants are hospitalized until the implants are removed. Thus, only permanent implants are potentially affected by this rulemaking. 
Table 4.2 Estimated Radiopharmaceutical Use for Diagnostic Procedures in the U.S. in $1993^{(1)}$

\begin{tabular}{|c|c|c|c|}
\hline $\begin{array}{c}\text { Examination Type } \\
\text { (Radiopharmaceutical) }\end{array}$ & \multicolumn{2}{|c|}{$\begin{array}{l}\text { Average Activity } \\
\text { per Examination } \\
(\mathbf{M B q}(\mathbf{m C i}))\end{array}$} & $\begin{array}{c}\text { Total No. of } \\
\text { Examinations } \\
(\times 1,000)\end{array}$ \\
\hline $\begin{array}{l}\text { - Tc-99m DTPA } \\
\text { - Tc-99m O } \\
\text { (2) }\end{array}$ & $\begin{array}{l}740 \\
740\end{array}$ & $\begin{array}{l}(20) \\
(20)\end{array}$ & $\begin{array}{l}450 \\
450\end{array}$ \\
\hline$\frac{\text { Hepatobiliary }}{- \text { Tc-99m IDA }}$ & 185 & (5) & 198 \\
\hline$\frac{\text { Liver }}{- \text { Tc-99m sulfur colloid }}$ & 185 & (5) & 1,578 \\
\hline$\frac{\text { Bone }}{- \text { Tc-99m phosphate }}$ & 740 & (20) & 2,007 \\
\hline$\frac{\text { Lung Perfusion }}{- \text { Tc-99m MAA }}$ & 185 & (5) & 871 \\
\hline$\frac{\text { Lung Ventilation }}{-\mathrm{Xe}-133}$ & 370 & (10) & 449 \\
\hline $\begin{array}{l}\text { Thyroid } \\
\text { - Tc-99m O4 } \\
- \text { I-131 } \\
- \text { I-123 }\end{array}$ & $\begin{array}{r}185 \\
3.7 \\
11.1\end{array}$ & $\begin{array}{l}(5) \\
(0.1) \\
(0.3)\end{array}$ & $\begin{array}{r}600 \\
75 \\
75\end{array}$ \\
\hline $\begin{array}{l}\frac{\text { Renal }}{\text { - Tc-99m DTPA }} \\
\text { - I-131 hippuran }\end{array}$ & $\begin{array}{l}740 \\
9.3\end{array}$ & $\begin{array}{l}(20) \\
(0.25)\end{array}$ & $\begin{array}{l}157 \\
105\end{array}$ \\
\hline $\begin{array}{l}\text { Cardiovascular } \\
\text { - Tc-99m RBC(2) } \\
\text { - Tl-201 chloride } \\
\text { - Tc-99m phosphate }\end{array}$ & $\begin{array}{l}740 \\
111 \\
740\end{array}$ & $\begin{array}{r}(20) \\
(3) \\
(20)\end{array}$ & $\begin{array}{l}421 \\
421 \\
211\end{array}$ \\
\hline $\begin{array}{l}\text { Tumor } \\
\text { - Ga-67 citrate }\end{array}$ & 111 & (3) & 134 \\
\hline Total & & & 8,202 \\
\hline
\end{tabular}

(1) Based on ME85; and personal communication, F. A. Mettler, March 1993, but adjusted for the 1993 U.S. population.

(2) DTPA is diethylene-triamine pentacetic acid; IDA is imino diacetic acid; MAA is macro-aggregated albumin, and $R B C$ is red blood cells. 
Table 4.3 Age and Sex Distribution of Patients Having Nuclear Medicine Examinations

\begin{tabular}{cccc}
\hline Age & $\begin{array}{c}\text { Male } \\
(\%)\end{array}$ & $\begin{array}{c}\text { Female } \\
(\%)\end{array}$ & $\begin{array}{c}\text { Total } \\
(\%)\end{array}$ \\
\hline$<15$ & 0.9 & 0.7 & 1.6 \\
$15-29$ & 3.3 & 4.9 & 8.2 \\
$30-44$ & 5.2 & 8.7 & 13.9 \\
$45-64$ & 15.8 & 21.6 & 37.4 \\
$>64$ & 17.0 & 21.9 & 38.9 \\
\hline
\end{tabular}

Source: ME86.

\subsubsection{Radiopharmaceuticals Used in Therapy}

The in-vivo use of radiopharmaceuticals in therapy is based on the ability to differentially deliver lethal radiation doses to the selected target tissue.

The choice of radionuclides is based on specific physical characteristics. Most desirable are beta emitters that can deliver intense irradiation of target cells while sparing the surrounding tissues. In contrast to diagnostic procedures for which the gamma emission is essential, the emission of energetic gammas is undesirable for therapeutic purposes since it results in unwanted irradiation of surrounding healthy tissues and doses to individuals in close proximity to the patient. In recent review articles, Verbruggen (VE90) and Hoefnagel (HO91) identified a list of available tumor-seeking radiopharmaceuticals (Table 4.4). The more significant therapeutic applications are described below.

\section{Hyperthyroidism}

Hyperthyroidism is characterized by an increased production of thyroid hormone. Hyperthyroidism is most commonly associated with Graves' Disease. Graves' Disease is an autoimmune disease in which the body's own immune system is directed against cellular and secretary products of the thyroid gland. Hyperthyroidism can also be the result of excessive hormone production by a single "toxic" nodule, thyroid carcinomas, and medications inclusive of potassium iodide.

Hyperthyroidism is not a condition reportable to public health agencies. As a result, data on rates of occurrence and treatment must be inferred. Incidence of hyperthyroidism is reported at 3 per 10,000 adults per year, with peak incidence occurring between 30 and 50 years of age (DG79).

From the most recent data (1990) available from the U.S. Bureau of the Census, it can be assumed that about 75 percent of the U.S. population (approximately 191,500,000 persons) is 18 years of age or older. Thus, it can be estimated that about 57,500 individuals per year require medical treatment for hyperthyroidism.

Although medical treatment may in some cases involve the use of anti-thyroid drugs or surgery, it may be assumed that about 85 percent of the cases of hyperthyroidism are treated with therapeutic doses of iodine-131 (personal communication, M. Polycove, November 1993). The resulting estimate is about 50,000 treatments per year.

In the past, therapeutic quantities of iodine-131 for treatment of hyperthyroidism tended to be of a magnitude that would reduce the hormone production of the hyperactive thyroid gland to normal levels. However, experience demonstrated that over a period of years the therapy-induced euthyroidal (normal or healthy thyroid) condition deteriorated to one of hypothyroidism requiring thyroid hormone replacement therapy. As a result, hyperthyroid therapy today involves ablation of the thyroid using doses of iodine-131 in the range of 550 to 1,100 megabecquerels (15 to 30 millicuries). Such doses quickly result in the total loss of thyroid function and the patient is given hormone replacement therapy from the 
Table 4.4 Radiopharmaceuticals for Radiotherapy

\begin{tabular}{|c|c|c|}
\hline Site/Mechanism & Radiopharmaceutical & Application \\
\hline \multicolumn{3}{|l|}{ Intracellular } \\
\hline DNA incorporation & ${ }^{125} \mathrm{I}-\mathrm{IUdR}$ & Chorioncarcinoma \\
\hline Metabolic & $\begin{array}{l}{ }^{131} \text { I-iodide } \\
{ }^{131} I /{ }^{125} \text { I-MIBG } \\
{ }^{32} \mathrm{P} \text {-phosphate } \\
{ }^{131} \text { I-Rose Bengal } \\
{ }^{131} \text { I-iodide }\end{array}$ & $\begin{array}{l}\text { Differentiated thyroid carcinoma } \\
\text { Neural crest tumors } \\
\text { Polycythaemia vera } \\
\text { Hepatoblastoma } \\
\text { Oncocytoma }\end{array}$ \\
\hline Steroid receptor & $\begin{array}{l}{ }^{80 \mathrm{~m}} \mathrm{Br} \text {-estrogens } \\
{ }^{125} \mathrm{I} \text {-tamoxifen }\end{array}$ & $\begin{array}{l}\text { Breast carcinoma } \\
\text { Breast carcinoma }\end{array}$ \\
\hline Non-specific & ${ }^{186} \mathrm{Re}(\mathrm{V})$-DMSA & Medullary thyroid carcinoma \\
\hline \multicolumn{3}{|l|}{ Cell surface } \\
\hline Hormone receptor & ${ }^{131} \mathrm{I}-\mathrm{SMS}$ analog & Neuroendocrine tumors \\
\hline Immunologic & $\begin{array}{l}{ }^{131} \mathrm{I} \text {-anti CEA } \\
{ }^{131} \mathrm{I}-\mathrm{B} 72.3 \\
{ }^{131} \mathrm{I}-\mathrm{HMFG} 1+2 \\
{ }^{131} \mathrm{I} /{ }^{90} \mathrm{Y}-\mathrm{OC} 125 \\
{ }^{131} \mathrm{I}-\mathrm{Lym}-\mathrm{I} \\
{ }^{131} \mathrm{I} \text {-anti pan B } \\
{ }^{131} \mathrm{I} /{ }^{90} \mathrm{Y} \text {-antiferritin } \\
{ }^{131} \mathrm{I} \text {-anti p97 } \\
{ }^{131} \mathrm{I} \text {-3F8/UJ31A }\end{array}$ & $\begin{array}{l}\text { Colon/medullary thyroid carcinoma } \\
\text { Colon/ovarian carcinoma } \\
\text { Ovarian carcinoma } \\
\text { Ovarian carcinoma } \\
\text { Leukemia/lymphoma } \\
\text { Lymphoma } \\
\text { HCC/Hodgkin's disease } \\
\text { Melanoma } \\
\text { Neuroblastoma }\end{array}$ \\
\hline \multicolumn{3}{|l|}{ Extracellular } \\
\hline Adsorption & $\begin{array}{l}{ }^{32} \mathrm{P} \text {-phosphate } \\
{ }^{89} \mathrm{Sr} /{ }^{85} \mathrm{Sr} \text {-chloride } \\
{ }^{186} \mathrm{Re}-\mathrm{Sn}-\mathrm{HEDP} \\
{ }^{153} \mathrm{Sm}-\mathrm{EDTMP} \\
{ }^{131} \mathrm{I}-\mathrm{BDP} 3 \\
{ }^{90} \mathrm{Y} \text {-citrate/EDTMP }\end{array}$ & $\begin{array}{l}\text { Bone metastases } \\
\text { Bone met/osteosarcoma } \\
\text { Bone metastases } \\
\text { Bone met/osteosarcoma } \\
\text { Bone metastases } \\
\text { Bone metastases }\end{array}$ \\
\hline Cells & ${ }^{114 m}$ In-A31 cells & Lymphoma \\
\hline Intracapillary & $\begin{array}{l}{ }^{131} \text { I-lipiodol } \\
{ }^{32} \mathrm{P} \text {-resin microspheres } \\
{ }^{90} \mathrm{Y} \text {-glass microspheres } \\
{ }^{90} \mathrm{Y} \text {-resin particles }\end{array}$ & $\begin{array}{l}\text { Liver tumors } \\
\text { Liver tumors } \\
\text { Liver tumors/sarcoma } \\
\text { Liver tumors/sarcoma }\end{array}$ \\
\hline Intracavitary & $\begin{array}{l}{ }^{32} \mathrm{P} /{ }^{90} \mathrm{Y} /{ }^{186} \mathrm{Re}-\text { colloids } \\
{ }^{32} \mathrm{P} \text {-colloids } \\
{ }^{198} \mathrm{Au} /{ }^{32} \mathrm{P} \text {-colloid } \\
{ }^{131} \mathrm{I} /{ }^{90} \mathrm{Y} \text {-antibodies } \\
{ }^{198} \mathrm{Au} \text {-colloid } \\
{ }^{90} \mathrm{Y} \text {-citrate/silicate } \\
{ }^{165} \mathrm{Dy} \text {-FHMA } \\
{ }^{186} \mathrm{Re} \text {-colloid } \\
{ }^{169} \mathrm{Er} \text {-citrate }\end{array}$ & $\begin{array}{l}\text { Astrocytoma/cystic craniopharyngioma } \\
\text { Malignant effusions } \\
\text { ALL intrathecal therapy } \\
\text { Malignant effusions } \\
\text { Synoviorthesis } \\
\text { Synoviorthesis } \\
\text { Synoviorthesis } \\
\text { Synoviorthesis } \\
\text { Synoviorthesis }\end{array}$ \\
\hline
\end{tabular}

Sources: HO91; VE90. 
onset (personal communication, F. A. Mettler, March 1993).

\section{Thyroid Nodules}

Single or multiple nodules of sufficient size may cause obvious enlargement of the thyroid. A nodule(s) refers to a replacement of the normal homogeneous cytostructure of the thyroid with a histologic pattern ranging from colloid-filled cysts and colloid adenomas to follicular adenomas. Since the incidence is 4 to 5 times as great in women as in men, and since it develops and progressively increases in size during life, it is most frequently found in females 50 to 70 years of age. It is not uncommon for nodules to remain undetected until a post-mortem examination.

Small nodules in euthyroid subjects require no therapy. If the gland is grossly enlarged and causes a cosmetic problem or tracheal compression, treatment may be indicated along with thyroid hormone replacement therapy.

A small percentage of thyroid nodules tend to produce thyroid hormones uncontrollably and in excess (i.e., the nodule is not under the regulatory control of the pituitary gland and is clinically referred to as toxic nodular goiter). The presence of these autonomously functioning thyroid nodules leads to hyperthyroidism (thyrotoxicosis).

Toxic nodular goiter, like Graves' Disease, may be treated surgically (thyroidectomy) or by therapeutic dose(s) with radioactive iodine. Estimates of the frequency of radioactive iodine treatment for this condition are included under the estimates for hyperthyroid treatment above.

\section{Thyroid Cancer}

There is no nationwide cancer registry that accurately defines the number of new cases of cancer diagnosed each year. However, the American Cancer Society (ACS) annually publishes data on cancer incidence and patient survival based on information provided by the National Cancer Institute's Surveillance, Epidemiology, and End Results (SEER) program.

The ACS estimates of U.S. cancer cases diagnosed for the most recent year, 1992, are based on age-specific incidence rates from the SEER program for 1986-1988 applied to the
Census Bureau's population projections for 1992. The ACS's estimate of new thyroid cancers in 1992 , is 12,500 (ACS93). This report assumes that about 10,000 cases per year will be treated with therapeutic doses of iodine- 131 .

The quantities of iodine-131 used in thyroid cancer therapy depend upon the type of cancer, the status of the cancer, and the degree of uptake and retention of iodine- 131 by residual cancerous thyroid tissue. As a result, current therapeutic doses range from 1,850 to 11,100 megabecquerels (50 to 300 millicuries) (personal communications, F. A. Mettler and K. L. Miller, March 1993).

\section{Therapy for Polycythemia Vera}

Since the introduction of radiophosphorus in 1936, patients with polycythemia vera (PV) have been treated successfully with this radioisotope to control rather than cure this disease. Polycythemia vera is a relatively rare disease that is characterized by an autonomous proliferation of marrow cells leading to an over production of red blood cells and white blood cells. Typically, phosphorous-32 (P-32) is administered intravenously in doses of 110 to 185 megabecquerels ( 3 to 5 millicuries) per treatment over a period of time with average cumulative quantities of 740 megabecquerels (20 millicuries) per patient (MO65). Since phosphorous-32 is a pure beta emitter, treatments using phosphorous-32 would not be affected by the rulemaking and need not be considered further in this analysis.

\section{Bone Therapy}

Since the use of radioactive strontium for the treatment of bone metastases was first described in early 1942 (PE42), bone therapy has included other radionuclides. Bone therapy may involve the treatment of primary bone tumors such as osteosarcoma (BL87) in which bone-seeking radiopharmaceuticals are in fact tumor seeking. Bone therapy may also be the treatment of painful skeletal metastases, which may be palliated by bone-seeking radionuclides. Although the literature references the palliative and tumor therapeutic use of these radionuclides (phosphorous-32: CH80, RO77; strontium-89 (Sr-89): BL88, KL87, SI85, RO87, ROE90; rhenium-186 (Re-186): KE87, MA88, SC90; samarium-153 (Sm-153): TU89, LA90), there are no data bases and no studies have been 
performed that would allow quantitative estimates regarding the number of patients given bone therapy with radiopharmaceuticals. As stated previously, phosphorous-32 need not be considered and the other therapies are performed so seldom that they have negligible impact in comparison with the radioiodines.

\section{Therapy with Radiolabelled Cells}

For lymphoid cell malignancies, the tumor cells (i.e., lymphocytes) may retain their ability to migrate and recirculate into the lymphoreticular tissues (i.e., spleen, liver, bone marrow, and lymph nodes). The harvesting, labelling, and reinjection of lymphocytes has been demonstrated to deliver therapeutic levels of radiation doses to tumors of the lymphoreticular system (CO87). Indium-114labelled lymphocytes have a potential therapeutic role in the management of lymphoma, and clinical studies are underway. Because use of this new therapy is not widespread, its impact may be omitted in the analysis, but it should be noted that use of a dose-based methodology provides a means to determine the quantities for which release may be authorized.

\section{Intra-Arterial Therapy}

Some primary tumors as well as metastatic lesions are highly vascularized. Direct arterial injection with insoluble radiolabelled particulates that lodge in arterioles and capillaries of the tumor is the basis of this form of therapy (ZI84; EH87). Insoluble carriers of radionuclides that have been clinically tested include iodine-131-labelled oil contrast medium, iodine-131-lipoidal or -ethiodol (PA87), yttrium-90-glass microspheres (HE88), and yttrium-90 (Y-90) resin particles (ROE90). Since these therapies are so seldom used, their impact may be ignored in this analysis.

\section{Intracavitary Tumor Therapy}

For tumors that are spread over the serosal linings of the body cavities or for ascites tumors, one approach to delivering therapeutic doses of radiation is to inject the radiopharmaceutical directly into the body cavity. For this approach, colloids, chelates, and, more recently, monoclonal antibodies labelled with gold-198 (Au-198), phosphorous-32, yttrium-90, or iodine-131 can be used.
Initially, gold-198 colloids were used, but phosphorous-32 is now preferred due to its longer half-life, more energetic beta particles, and the absence of gamma radiation. Intracavitary radionuclide therapy with phosphorous- 32 in quantities of 185 to 370 megabecquerels ( 5 to 10 millicuries) has been applied to malignancies involving the pleural, pericardial, and peritoneal cavities (JA81; MA78; KA81).

More recently, iodine-131- or yttrium-90-labelled tumor-associated monoclonal antibodies have been used in intracavitary therapy (PE86; FI89; RI90) in doses of 740 to 2,220 megabecquerels (20 to 60 millicuries). Superiority of monoclonal antibodies over colloids is expected due to the enhanced affinity of the labelled antibody for the target cells. At present, these therapies are rarely used and thus have no impact in comparison with radioiodines.

\section{Radioimmunotherapy}

Radioimmunotherapy involves the use of radiolabelled antibodies directed against tumor-specific antigens such as the carcinoembryonic antigen (CEA) and ferritin. Only a very limited number of cancer patients have been treated experimentally with radiolabelled antibodies in combination with chemotherapy and external beam irradiation. Among cancers treated are hepatomas, Hodgkin's disease, and non-Hodgkin's lymphoma (OR85; LE85; NE90). In the past, radioimmunotherapy involved the use of iodine-131- and yttrium-90labelled polyclonal antibodies raised against tumor-associated antigens in a variety of animal species. Based on avidity of tumor cells and exposure considerations of the bone marrow, single doses of 370 to 1,110 megabecquerels (10 to 30 millicuries) have been used.

The development of the hybridoma technique by Kohler and Milstein (KO75) has caused significant shift in radioimmunotherapy. The hybridoma technique allows the development of monoclonal antibodies against tumor-associated antigens. At this time, however, the use of radiolabelled monoclonal antibodies for therapeutic applications has been limited to experimental treatments. At present, these therapies are rarely used and thus have no impact in comparison with radioiodines. 


\subsubsection{Radioactive Materials Used in Permanent Implants (Brachytherapy)}

In-situ radiotherapy may involve permanent implants or brachytherapy. Brachytherapy has been around almost since the discovery of $X$ rays. Brachytherapy can be divided into temporary implantation using high activity sources or permanent brachytherapy using the interstitial implantation of encapsulated radioactivity. In 1911, Pasteau reported the first treatment of prostate cancer by brachytherapy using radium inserted through a urethral catheter (PA11). Currently, iridium-192 is the radionuclide of choice for temporary implantation. For temporary implantation, patients may be retained in the hospital for reasons that are independent of radiological considerations. Radionuclides used for temporary implants are, therefore, of no concern to this report and will not be discussed further.

Over the past 20 years, several radionuclides have been introduced to brachytherapy, allowing for the permanent implantation of radioactive "seeds." Seeds are miniature capsules that are strategically inserted within a solid tumor and over the period of their decay deliver a lethal dose of radiation to tumor cells within a short distance of the implant. The major advantage of brachytherapy over external irradiation in the treatment of solid tumors is the favorable ratio of dose delivered to tumor cells versus normal tissue. This is particularly true of prostate cancer where the surrounding normal tissue includes the bladder, rectum, and urethra. The presence of these normal tissues limits the dose of external beam radiation therapy that can be administered safely to the prostate to approximately 7,000 rads (PO93).

The radionuclides primarily used in permanent implants are iodine-125 (I-125) and palladium-103 (Pd-103). Less frequently used radionuclides include gold-198 and ytterbium-169 (Yb-169).

The most frequently used radionuclide in permanent implants is iodine-125, which has the advantage of an extremely low energy ( $27 \mathrm{keV})$ photon and a half-life of 60 days. Besides minimizing dose to surrounding healthy tissue, the low photon energy also limits doses to hospital personnel and others when compared to temporary implants with iridium-192 (Ir-192) or permanent implants with gold-198 (CL89, RU92).
Although iodine- 125 implants are most commonly used to treat cancer of the prostate (FU91, MO88, DE86, HE82, WH88, PR92), they have also been used on a very limited basis for brain tumors (AG92, SC92, OS92), carcinomas of the pancreas (MO92), non-oat cell lung carcinomas (FL92), breast cancers (RU92), and tumors of the head, neck, and eye.

Palladium-103 seeds were developed for use in brachytherapy to reduce some of the problems associated with iodine-125. Its average photon energy of $21 \mathrm{keV}$ is lower than iodine-125, but, given its shorter 17 day half-life, it has a higher initial dose rate. Recently, palladium-103 seeds have been developed with the same physical parameters as iodine- 125 seeds to ensure compatibility with the brachytherapy tubes and templates used for iodine implantation (ME90).

Ytterbium-169 has been hailed as a replacement for iodine-125 in brachytherapy. Compared to iodine- 125 and palladium-103, it has a slightly higher initial dose rate, and its average $93 \mathrm{keV}$ beta energy allows for a more favorable dose distribution and negligible tissue self-attenuation (P090). However, its use as a permanent implant is nominal due to the presence of a small (less than 3 percent) average photon peak at $300 \mathrm{keV}$, that can significantly impact radiation doses to individuals in proximity to the patient.

Gold-198 implants have been used in a few instances of prostate cancer (FR88, CA88). The potential advantage of delivering a high dose within a relatively short time, however, is offset by its energetic gamma emissions, which has caused its use in recent years to fall into disfavor and be used only rarely (CA87).

Table 4.5 lists information on radionuclides used in brachytherapy permanent implants relative to factors that affect the external dose rates of implants.

A thorough search of the literature and personal communications with several prominent members of the medical and scientific community (see Acknowledgements) indicates that there is no published data available to quantify the annual number of cancer patients receiving permanent implants. 


Table 4.5
Data

The scientific literature and consensus opinion among the experts identified in the acknowledgments to this report does, however, support the following:

1. permanent implants are currently considered an appropriate treatment for only a few sites of solid tumors;

2. among the cancer sites for which permanent implants are currently employed, prostate cancer represents the overwhelming majority;

3. among the 132,000 annual new cases of prostate cancer (ACS93), only a small fraction is treated with permanent implants; and,

4. for the purposes of this analysis, implants involving gold-198 (largely discontinued) and ytterbium-169 (isolated use only) may be ignored.

In the absence of documented clinical data, information was sought from the implant vendors on numbers of administrations and typical activities of radioactive material used per administration. Currently, there are only three vendor sources. Vendor supplied data suggests that approximately 2,000 implants involving iodine-125 are performed annually, at activities ranging from 1,110 to 1,850 megabecquerels ( 30 to 50 millicuries). For palladium-103, approximately 1,500 implants are performed annually, at activities ranging from 2,775 to 4,625 megabecquerels (75 to 125 millicuries).

\subsubsection{Summary of Therapeutic Administrations}

Table 4.6 summarizes the estimates of the quantities of gamma-emitting radioactive materials used in therapeutic administrations and the numbers of each therapy currently performed annually.

\subsection{Assessment of Doses to Individuals Exposed to Patients Administered Radioactive Materials}

To identify the potential impacts associated with each of the alternatives, it is necessary to know the magnitude of doses that could be received by an individual exposed to a patient who has been administered radioactive materials. While exposure can occur via any of the elimination pathways by which radionuclides are removed from the body (e.g., urine, feces, sweat, saliva, exhalation), experience indicates that for iodine-131 and other gamma emitters, these pathways will generally be insignificant in relation to the doses that can result from exposure to the direct gamma radiation from the patient. 
Table 4.6 Number of Annual Therapeutic Administrations in the U.S. (significant gamma-emitting radionuclides only)

\begin{tabular}{lcccc}
$\begin{array}{l}\text { Therapeutic } \\
\text { Procedure }\end{array}$ & $\begin{array}{c}\text { Radionuclide } \\
\text { Employed }\end{array}$ & \multicolumn{2}{c}{$\begin{array}{c}\text { Activity per } \\
\text { Administration } \\
\text { (MBq (mCi) })\end{array}$} & $\begin{array}{c}\text { Estimated No. of } \\
\text { Administrations } \\
\text { (per year) }\end{array}$ \\
\hline $\begin{array}{l}\text { Thyroid Ablation for } \\
\text { Hyperthyroidism }\end{array}$ & I-131 & $555-1,110$ & $(15-30)$ & 50,000 \\
$\begin{array}{l}\text { Thyroid Cancer } \\
\text { Permanent Implant }\end{array}$ & I-131 & $1,850-11,100 \quad(50-300)$ & 10,000 \\
Permanent Implant & I-125 & $1,110-1,850 \quad(30-50)$ & 2,000 \\
\hline \multicolumn{1}{c}{ Total } & Pd-103 & $2,775-4,625$ & $(75-125)$ & 1,500 \\
\hline
\end{tabular}

This section of the report assesses the dose to individuals exposed to patients who have been administered radioactive materials. For expediency, a two-tiered approach is employed.

The first tier serves as a baseline and may be viewed as a screening method. Consequently, this first screening tier employs conservative assumptions and represents upper-bound values. Therefore, procedures involving quantities of radionuclides that are less than those defined by the screening calculation can be eliminated from further consideration. Procedures employing quantities in excess of the first tier screening quantities are subsequently assessed using parameters that are more realistic.

\subsubsection{Methodology for Calculating Direct Gamma Dose}

A basic calculation in gamma-ray dosimetry is the radiation distribution around a point source. In air, the absorption of even low-energy photons is small and can, therefore, be neglected for small distances from the source. As a result, the dose around a point source follows the inverse square law. If a point source is placed at the center of an imaginary sphere, the same number of gamma rays pass through the surface independent of the sphere's radius $r$. Since the surface area is proportional to $r^{2}$, the number of quanta passing $1 \mathrm{~cm}^{2}$ of surface area is proportional to $1 / r^{2}$. Therefore, if the dose rate is known at $1 \mathrm{~cm}$ from the point source, it can be easily determined at any distance.
After a single administration $q_{o}$ of a radionuclide, the body content $q(t)$ at time $t$ diminishes with time according to the equation (LO56):

$$
\frac{d q(t)}{d t}=-E(t)-\lambda q_{o},
$$

where $E(t)=$ the amount $(\mathrm{mCi})$ of radionuclide excreted per unit time at time $t$,

$\lambda=$ the radioactive decay constant.

The rate of radionuclide excretion may be complex if more than one biological compartment is involved. For such instances, variation of $q(t)$ follows the exponential decay relationship characterized by the physical half-life $T_{p}$ and biological half-life $T_{b}$ of the radionuclide for each compartment.

The gamma-ray dose rate constant $\Gamma$ commonly expresses the dose rate per hour at $1 \mathrm{~cm}$ in air for a 37-megabecquerel (1-millicurie) point source of a given radionuclide. The gamma dose rate constant $\Gamma$ may be measured directly if the disintegration rate is accurately known or it may be calculated from known physical constants.

Table 4.7 identifies the specific gamma-ray constants and corresponding dose rates at 1 meter for principal radiopharmaceuticals employed in diagnostic and therapeutic procedures.

Thus, for an initial activity $q_{o}$ (in megabecquerels or millicuries), the external dose rate $R_{\gamma}(t)$ of a given radionuclide point source is defined as follows (LO56): 
Table 4.7 Specific Gamma-Ray Constants and Dose Rates at 1 Meter

\begin{tabular}{lccc} 
Radionuclide & $\begin{array}{c}\text { Half-Life } \\
\text { (days) }\end{array}$ & $\begin{array}{c}\text { Specific } \boldsymbol{\gamma} \text {-Ray Constant } \boldsymbol{\Gamma} \\
\text { (R/mCi-h at } \mathbf{~ c m})\end{array}$ & $\begin{array}{c}\text { Exposure Rate at } \\
\text { 1 Meter per mCi } \\
\text { (mR/mCi-h) }\end{array}$ \\
\hline Ga-67 & 3.25 & 1.1 & 0.11 \\
I-123 & 0.55 & 0.7 & 0.07 \\
I-125 & 60.2 & 2.0 & 0.20 \\
I-131 & 8.04 & 2.2 & 0.22 \\
Pd-103 & 17.0 & 1.7 & 0.17 \\
Tc-99m & 0.25 & 0.7 & 0.07 \\
Tl-201 & 3.08 & 0.9 & 0.09 \\
\hline
\end{tabular}

Sources: NCRP70; personal communication, R. Nath, March 1993).

$$
R_{\gamma}(t)=\frac{\Gamma q_{0}}{r^{2}} e^{-\frac{0.693 t}{T_{t y}}}
$$

where

$$
T_{e f f}=\frac{T_{p} \times T_{b}}{T_{p}+T_{b}}
$$

The total dose $D_{\gamma}(t)$ at any time $t$ is found by integrating the dose rate $R_{\gamma}(t)$ from time $t_{0}$ to the time $t$. The total dose for a given time interval is therefore:

$$
D_{\gamma}(t)=\int_{0}^{t} R_{\gamma}(t) d t
$$

Using Eq.(2)

$$
D_{\gamma}(t)=\frac{\Gamma q_{0}}{r^{2}} \int_{0}^{t} e^{-\frac{0.693 t}{T_{s t}}} d t,
$$

from which it follows that

$$
D_{\gamma}(t)=\frac{1.44 \Gamma q_{0} T_{e f f}}{r^{2}}\left(1-e^{-\frac{0.693 t}{T_{s f}}}\right) .
$$

For a time period in which total decay takes place, Eq. (6) is simplified and the total dose is defined by $D_{\gamma}(\infty)$ as follows:

$$
D_{\gamma}(\infty)=1.44 \frac{\Gamma q_{0} T_{e f f}}{r^{2}}
$$

\subsubsection{Screening Calculations}

To determine which, if any, of the diagnostic and therapeutic procedures involving administration of radioactive materials would be affected by the alternatives under consideration, a series of screening calculations were performed using Eq. (7) to calculate the total gamma dose to decay at 1 meter that would be delivered by the radionuclide modeled as a point source in air. The screening calculations used the physical half-lives of the radionuclides and did not consider biological elimination. In other words, the physical half-life was used in Eq. (7) in place of the effective half-life. The physical characteristics of the radionuclides are given in Table 4.7.

The results of the screening calculations are summarized in Table 4.8. Table 4.8 indicates that, except for a few procedures using iodine-131 to detect thyroid cancer, none of the other diagnostic procedures currently being performed have the potential to deliver a 1 millisievert $(0.1 \mathrm{rem})$ dose to an individual exposed to a patient. However, based on the screening procedure, additional consideration must be given to the therapeutic procedures and the diagnostic use of iodine- 131 . 
Table 4.8 Screening Calculation of Total Gamma Dose to Decay at 1 Meter Due to Administrations of Radioactive Materials

\begin{tabular}{|c|c|c|c|c|}
\hline \multirow{2}{*}{$\begin{array}{l}\text { Examination Type } \\
\text { (Radiopharmaceutical) }\end{array}$} & \multicolumn{2}{|c|}{$\begin{array}{l}\text { Activity per } \\
\text { Examination }^{(\mathbf{l})} \\
(\mathbf{M B q}(\mathbf{m C i}))\end{array}$} & \multicolumn{2}{|c|}{$\begin{array}{c}\text { Total Gamma Dose } \\
\text { To Decay at } 1 \text { Meter } \\
(\mathrm{mS}) \\
(\mathrm{rem}))\end{array}$} \\
\hline & & & & \\
\hline - Tc-99m DTPA ${ }^{(3)}$ & 740 & (20) & 0.1 & $(0.01)$ \\
\hline$-\mathrm{Tc}-99 \mathrm{~m} \mathrm{O}_{4}$ & 740 & (20) & 0.1 & $(0.01)$ \\
\hline$\frac{\text { Hepatobiliary }}{- \text { Tc-99m IDA }}$ & 185 & (5) & 0.03 & $(0.003)$ \\
\hline$\frac{\text { Liver }}{-T c-99 m \text { sulfur colloid }}$ & 185 & (5) & 0.03 & $(0.003)$ \\
\hline$\frac{\text { Bone }}{- \text { Tc-99m phosphate }}$ & 740 & (20) & 0.01 & $(0.01)$ \\
\hline$\frac{\text { Lung Perfusion }}{- \text { Tc-99m MAA }}$ & 185 & (5) & 0.03 & $(0.003)$ \\
\hline Thyroid & & & & \\
\hline$-\mathrm{Tc}-99 \mathrm{~m} \mathrm{O}_{4}$ & 185 & $(5)$ & 0.03 & $(0.003)$ \\
\hline$-I-131$ & 3.7 & $(0.1)$ & 0.06 & $(0.006)$ \\
\hline - I-131 (maximum) ${ }^{(1)}$ & 370 & (10) & 6 & $(0.6)$ \\
\hline Cardiovascular & & & & \\
\hline $\begin{array}{l}\text { - Tc-99m RBC(3) } \\
\text { - Tc-99m phosphate }\end{array}$ & $\begin{array}{l}740 \\
740\end{array}$ & $\begin{array}{l}(20) \\
(20)\end{array}$ & $\begin{array}{l}0.1 \\
0.1\end{array}$ & $\begin{array}{l}(0.01) \\
(0.01)\end{array}$ \\
\hline$\underline{\text { Renal }}$ & & & & \\
\hline - Tc-99m DTPA & 740 & $(20)$ & 0.1 & $(0.01)$ \\
\hline - I-131 hippuran & 9.3 & $(0.25)$ & 0.15 & $(0.015)$ \\
\hline $\begin{array}{l}\text { Therapeutic Procedures } \\
\text { Thyroid Ablation (Hype }\end{array}$ & & & & \\
\hline$-\mathrm{I}-131$ & 1110 & (30) & 18.5 & $(1.85)$ \\
\hline Thyroid Cancer & & & & \\
\hline$-\mathrm{I}-131$ & 11,100 & $(300)$ & 185 & $(18.5)$ \\
\hline$\underline{\text { Permanent Implant }}$ & & & & \\
\hline$-\mathrm{I}-125$ & 1,850 & $(50)$ & 118 & $(11.8)$ \\
\hline - Pd-103 & 4,625 & (125) & 63 & $(6.3)$ \\
\hline
\end{tabular}

(1) For diagnostic procedures, the activity is the average per administration (see Table 4.2). The maximum diagnostic activity of $1-131$ is shown because it yields gamma doses exceeding the 1 -millisievert $(0.1-\mathrm{rem})$ screening value. For therapeutic procedures, the activity is the maximum per administration (see Table 4.6).

(2) Calculations assume no biological elimination and no attenuation of gamma rays in air, body of patient, or source capsule.

(3) DTPA is diethylene-triamine pentacetic acid, IDA is imino diacetic acid, MAA is macro-aggregated albumin, and RBC is red blood cells. 


\subsubsection{Estimate of Maximum Likely Doses to Individuals Exposed to Patients}

To determine the potential magnitude of the impacts on therapeutic administrations, considerably more realistic assessments were made of the doses that could result from exposure to a patient treated with each of the radionuclides used in therapy.

\subsubsection{Exposure Factor}

The release of a patient with radiopharmaceuticals has the potential for exposing other individuals who are near that patient. As such, essentially all members of society are to a varying extent at risk to exposure whether at home, work, or in a public facility (e.g. public transportation, restaurant, theater, store, sporting event, etc.). Doses among individuals who may come in contact with a released patient are highly variable and reflect the crucial, but difficult to define, parameters of time, distance, and shielding. Based on time and distance considerations, it is reasonable to conclude that for the overwhelming majority of released patients, the maximally exposed individual is likely to be the primary careprovider, the family, or any other individual who spends significant time close to the patient.

Based on time, distance, and shielding factors, which describe normal lifestyles of the U.S. population, it is highly unlikely that doses equal to spending 100 percent of time at a distance of 1 meter from a patient would result to any individual including a patient's spouse. As a standard medical practice, patients undergoing therapeutic treatments with radiopharmaceuticals are given firm instructions, both verbally and in writing, regarding basic principles on how to minimize doses to other individuals.

Given all considerations, a realistic estimate of the maximal likely dose to an individual exposed to a patient is 25 percent of the "Reference Dose" (i.e., dose-to-total decay at a distance of 1 meter).

The selection of 25 percent of the "Reference Dose" for estimating maximal likely exposure is an intuitive judgment based on the authors' judgment of time-distance combinations that are believed likely to occur when instructions to spend as little time close to the patient as possible are given. The value is also supported by empirical data. Harbert and Wells (HA74) monitored family members of three patients for external exposure. Table 4.9 summarizes key parameters of patient treatments and associated measured doses to family members. The last column of Table 4.9 provides dose estimates that would have been predicted based on the 25 percent Reference Dose Model adopted in this report.

\subsubsection{Iodine Retention by the Thyroid}

For therapeutic administrations of iodine-131, the total gamma dose to decay at 1 meter was calculated based upon specific uptake, retention, and elimination rates for hyperthyroid and euthyroid conditions. For thyroid ablation, the patient is considered hyperthyroid; for thyroid cancer, the patient is conservatively considered euthyroid or having normal thyroid function. For iodine- 125 and palladium-103 implants, the total gamma dose to decay at 1 meter was calculated considering attenuation by the source capsule and the surrounding tissues.

Iodide is concurrently removed from the blood by both the thyroid and by the kidneys. The concurrent removal of free iodide from the blood by thyroid uptake and urinary excretion yields a biological half-life of blood iodide of about 5 to 6 hours (ST88). This implies that about 95 percent of iodide (and therefore radioiodide) is cleared from the blood in the first 24 hours following an oral or i.v. administration. The kinetics of these two competing removal mechanisms of iodide from the blood forms the basis of the iodide uptake fraction from the blood by the thyroid.

\section{Organ Uptake Fraction}

The fraction of iodide taken up from the blood by the thyroid varies widely among individuals because of differences in dietary iodine levels and metabolic factors that are age and sex related. For healthy adult (euthyroid) individuals in the U.S. with an average daily dietary intake of iodide, the daily thyroidal uptake of about 60 to $100 \mu \mathrm{g}$ of iodide represents a 9 to 30 percent fractional uptake, with an average fractional intake of 17 percent. Under conditions of hyperthyroidism, the fractional uptake is considerably higher and 


\begin{tabular}{ccccc} 
Patient & $\begin{array}{c}\text { Total } \\
\text { Activity } \\
\text { Administered } \\
\text { (mCi) }\end{array}$ & $\begin{array}{c}\text { Body Burden } \\
\text { at Time of } \\
\text { Discharge } \\
\text { (mCi) }\end{array}$ & $\begin{array}{c}\text { Measured } \\
\text { Doses to } \\
\text { Family } \\
\text { Member } \\
\text { (mrem) }\end{array}$ & $\begin{array}{c}\text { Predicted } \\
\text { Dose Based on } \\
\text { 25\% of } \\
\text { Reference } \\
\text { Dose } \\
\text { (mrem) }\end{array}$ \\
\hline 1 & 210 & 25.2 & $146,128,55$ & 176 \\
2 & 311 & 26.4 & $91,36,36$ & 184 \\
3 & 209 & 18.4 & 146,73 & 128 \\
\hline
\end{tabular}

Source: HA74.

may reach levels as high as 75 to 80 percent (ST88).

Since elemental iodine is heavily concentrated in the thyroid gland, iodine-131, a beta-gamma emitter, has found extensive applications in diagnostic and therapeutic procedures involving the thyroid. Owing to its physical, chemical, and biological characteristics, iodine- 131 is the most frequently used therapeutic radiopharmaceutical and thus of primary concern in a discussion of regulatory release criteria.

\section{Biological Half-Life}

The biological half-life of elemental iodide is primarily governed by metabolic utilization and retention of organified iodide. For euthyroid conditions, the thyroid releases approximately 60 to $100 \mu \mathrm{g}$ of hormonal iodide daily. Empirical studies by Dunning and Schwarz (DU81) show that the elimination of iodide from the thyroid among individuals may vary with biological halflives of 21 days to over 300 days. Under conditions of extreme hyperthyroidism (e.g., Graves' disease), enhanced elimination of iodide may reach biological half-life values as short as 7 days (ST88).

The Quantitative Assessment of the Uptake, Retention, and Excretion of Iodine-131

There is general agreement that retention of stable iodide introduced into the blood stream declines with time according to a two-term exponential equation (ICRP79):

$$
R(t)=F_{1} e^{\frac{-0.693 t}{T_{b 1}}}+F_{2} e^{\frac{-0.693 t}{T_{b 2}}}
$$

where $F_{1}+F_{2}=1.0$; and where $F_{1}$ and $F_{2}$ represent the extrathyroidal and thyroidal fraction of iodide, respectively,

$$
\begin{aligned}
T_{b 1}= & \text { biological half-life of } \\
& \text { extrathyroidal iodide, }
\end{aligned}
$$

$T_{b 2}=$ biological half-life of iodide following uptake by the thyroid,

$$
t=\text { time after administration of }
$$
iodide.

Because radioactive nuclides of iodine are also lost by radioactive decay, the retention equation Eq. (8) must be modified accordingly:

$$
R(t)=F_{1} e^{\frac{-0.693 t}{T_{1 ब ๘}}}+F_{2} e^{\frac{-0.693 t}{T_{2 f t}}}
$$

where

$$
\begin{aligned}
& T_{1 \text { fff }}=\frac{T_{b 1} \times T_{p}}{T_{b 1}+T_{p}}, \\
& T_{2 \text { eff }}=\frac{T_{b 2} x T_{p}}{T_{b 2}+T_{p}},
\end{aligned}
$$

and $T_{p}=$ the physical half-life of iodine- 131 . 
Empirical measurements of the fractional uptake following a single administration have been reported by many investigators. For North American adults with daily dietary intakes of 100 to $300 \mu \mathrm{g}$ of iodide, the $F_{2}$ value generally applied to adults is 0.3 (ICRP79). Empirical measurements also indicate that representative values for $T_{b 1}$ and $T_{b 2}$ vary between 4 to 6 hours and 50 to 100 days, respectively. Values of 5 hours and 68 days represent average values for $T_{b 1}$ and $T_{b 2}$ and will be used for computational purposes in this report (LO56). Table 4.10 identifies appropriate values that may be used to calculate the total retention of iodine-131 under euthyroid and hyperthyroid conditions.

Substituting appropriate values from Table 4.10 into Eq. (9) yields the following retention equations:

\section{Euthyroid Condition:}

$$
R(t)=0.7 e^{-3.47 t}+0.3 e^{-0.096 t} .
$$

\section{Hyperthyroid Condition:}

$$
R(t)=0.4 e^{-11.2 t}+0.6 e^{-0.122 t} .
$$

Eqs. (12) and (13) reveal that in the first 24 hours nearly all of the $F_{1}$ fraction has been eliminated (the $F_{1}$ fraction is that quantity which is not taken up by the thyroid and is largely eliminated by urinary excretion at discrete intervals over the first 24-hour period under normal conditions) and that post-24 hours the body burden of iodine-131 is in essence defined by the $F_{2}$ fraction or thyroid burden. While these equations describe the retention in the body they do not include the iodide contained in the urine in the bladder. That iodide can be significant in the early hours after administration.

For hyperthyroidism, due to the complexities associated with the geometric distribution, uptake and biological elimination of iodide, a simple, conservative model assumes that (1) the $F_{1}$ fraction is eliminated by a single urinary voiding at $t$ equals 24 hours and (2) in the first 24 hours, all of the iodide is concentrated in the body as a point source (e.g., bladder). The total dose $D_{\gamma}(\infty)$ may, therefore, be established by adding the doses for two discrete time intervals: (1) 0 to 24 hours and (2) 24 hours to infinity. For the first 24 hours after administration, the effective half- life will equal the physical half-life of iodine- 131 . For the time interval of 24 hours to infinity, the effective half-life will assume the value 5.7 days.

For purposes of quantifying average body and thyroid burdens in thyroid cancer patients, a practical approach is to assume that (1) the residual cancerous tissue is normal (i.e., euthyroid) and (2) the iodine-131 is metabolized in a manner that conforms with a normal euthyroid condition. The total dose $D_{\gamma}(\infty)$ is established in an analgous manner to that described for hyperthyroidism above.

\subsubsection{Internal Exposure}

Upon oral administration or direct injection into the circulating blood, the normal processes of absorption, distribution, and excretion take place. Removal of radionuclides from the body may follow the pathways of urine, feces, sweat, saliva, and exhaled air.

Urine. Radionuclide excretion in the urine is the dominant and almost universal elimination pathway.

Feces. Radiopharmaceuticals retained or catabolized by the liver may be secreted into the gastrointestinal lumen via the bile. Biliary secretion of a radionuclide may be followed by intestinal reabsorption.

Sweat. Radionuclides present in the extracellular fluid will tend to be excreted in the sweat in accordance with the fraction that is unbound in the plasma.

Saliva. Salivary excretion of radionuclides is also proportional to the unbound or diffusible fraction in the plasma. However, salivary excretion is seldom an important elimination route, since nearly all saliva is swallowed rather than expectorated.

Milk. Radionuclide excretion via the mammary gland constitutes a potential exposure pathway to the breast-fed infant or child. This can be a very important pathway after the administration of radioiodines. Relatively small administrations of radioiodine to a breast-feeding mother can cause very large doses to the thyroid of the infant. Thus, precautions must be taken against breastfeeding after the administration of radioiodines. 
Table 4.10 Parameters for Use in Estimating Iodine-131 Retention

\begin{tabular}{lccccccc} 
& $\begin{array}{c}T_{p} \\
\text { (days) }\end{array}$ & $\begin{array}{c}T_{b 1} \\
\text { (days) }\end{array}$ & $\begin{array}{c}T_{1 \text { leff }} \\
\text { (days) }\end{array}$ & $\begin{array}{c}T_{b 2} \\
\text { (days) }\end{array}$ & $\begin{array}{c}T_{2 e f f} \\
\text { (days) }\end{array}$ & $F_{1}$ & $F_{2}$ \\
\cline { 2 - 8 } Euthyroid (adult) & 8.0 & 0.21 & 0.20 & 68 & 7.2 & 0.7 & 0.3 \\
Hyperthyroid (adult) & 8.0 & 0.063 & 0.062 & 20 & 5.7 & 0.4 & 0.6 \\
\hline
\end{tabular}

Exhaled Air. Exhalation is the principal pathway for the elimination of radioactive gases such as xenon-133, which is used for lung ventilation tests. Through passive diffusion, unbound iodide in the circulating blood may also be exhaled.

The potential for contamination by patients treated with radioiodine which may serve as a source for internal exposures to others have been assessed for various excreta pathways (BL71, MA73, NI80). Levels of iodine in urine, perspiration, saliva, and exhaled air are proportional to the blood levels of free or unbound iodide. Thus, maximum excretion rates are observed shortly after an administered dose. Excretion rates decline rapidly thereafter due to renal clearance and thyroidal uptake. While contamination through urinary excretion may be readily controlled by cautious but reasonable hygiene practices, contamination by other pathways inclusive of saliva, saliva spray (i.e., sneezing and coughing), perspiration, and breathing are more difficult to mitigate. In a thorough study of two patients treated for thyroid carcinomas, Nishizawa, et.al. (NI80) observed maximum excretion rates of iodine in exhalation, perspiration, and saliva of $3.2 \times 10^{-6} / \mathrm{hr}, 2.4 \times 10^{-6} / \mathrm{hr}$, and $6.3 \times 10^{-3} / \mathrm{hr}$ of the administered dose, respectively.

Buchanan and Bridle (BU70) estimated thyroid radioiodine activity in 39 subjects who, as family members, were associated with patients treated for hyperthyroidism. Administered quantities ranged from 148 to 740 megabecquerels (4 to 20 millicuries) per patient. Of the 39 patients, 28 were instructed to take precautionary measures to minimize exposure to family members. Eleven patients volunteered to disregard special precautions against contamination and minimizing spousal and family exposure. On the basis of one measurement per family, subject thyroid burdens ranged from less than 37 to 1,110 becquerels ( 1 to 30 nanocuries) with an average of 259 becquerels (7 nanocuries). Although the subjects were not monitored for external radiation exposure, thyroid dose equivalents may be assumed to be equal or less than the corresponding whole body exposures from external radiation.

In a 1978 study by Jacobson, et.al. (JA78), seven families were studied in which one family member had been treated with iodine-131 doses ranging from 296 to 5,500 megabecquerels (8 to 150 milicuries). Non-patient family members were assessed for external exposures by means of thermoluminescent dosimeters (TLDs) worn at the wrist for the full duration of exposure. Internal exposure (i.e., thyroid burden) was determined at discrete time intervals by means of a pair of 30 -inch $\mathrm{NaI}$ crystals. Although all family members proximal to the patient had measurable thyroid burdens, dose estimates in nearly all cases indicate that external exposures substantially exceeded internal thyroid dose equivalents. Moreover, the investigators also concluded that it " . . appears certain from our study of these subjects that for spouses, there is a relation between thyroid activity and intimacy. Of the 12 husbands and wives questioned, ... none were willing to adjust living habits with their spouses because of the radiation therapy. Most, however, are concerned for their children and are willing to listen to suggestions which minimize exposure to their children."

Although the number of studies and associated data regarding internal exposures are limited, existing information suggests that internal doses from intake of contamination are likely to be much less than external doses.

\subsubsection{Self-Shielding for Permanent Implants}

The modeling of doses from patients with implants is relatively simple because the encapsulated activity is not subject to the complex uptake and elimination of in-vivo administered radionuclides. Dose and dose rates, as a function 
of time, are therefore governed exclusively by the physical decay of the radionuclide. Table 4.5 provided dose rates at a distance of 1 meter for point sources in air having activities within the range of therapeutic implants. In Table 4.5, no attenuation of gamma rays within the source capsule or the patient's tissue was assumed.

Calculated doses and dose-rate values of point sources in air, however, cannot be assumed to represent implant conditions. A significant reduction in dose rate and exposure doses must be anticipated from the shielding effects of the source capsule and the tissue surrounding the implant. The linear absorption coefficient and corresponding soft tissue half-value layer for the low energy photon of iodine-125 and palladium-103 were identified in Table 4.5. For a prostate implant, tissues that serve to reduce photon flux about the patient include the soft and bone tissues of the thighs, pelvis, buttocks, abdomen, etc.

To assess the impact of tissue shielding by the patient, the medical health physicist of the Memorial Sloan Kettering Cancer Center was consulted (personal communication, J. St. Germain, March 1993). Based on empirical assessment involving patients with implants, tissue shielding for iodine-125 is likely to exceed 5 or more half-value layers (HVLs), which would reduce the dose and dose rate by a factor of at least 32. For palladium-103 implants, in which the HVL in tissue is less than one centimeter, the shielding afforded by the patient's tissue is even more extensive. For other implants involving the lungs, brain, pancreas, etc., tissue shielding values of similar magnitude can be assumed for an adult male and female. For certain implants involving primary cancers of the neck and head, overlying tissues may provide less than 5 HVLs of attenuation. In such instances, it is standard practice to provide the patient with a small portable "shield" which effectively attenuates all emissions (personal communications, C. Jacobs, August 1993, and R. Nath, J. St. Germain and K. Suphanpharian, March 1993). A shield consists of a vinyl sheet impregnated with lead and molded to fit the anatomical surface over the implant.

Table 4.11 provides estimates of the maximal likely doses to an individual from implants. Even for upper-bound activities of palladium-103, doses are not likely to exceed 1 millisievert $(0.1 \mathrm{rem})$ and may, therefore, be exempted from consideration in the cost-benefit analysis.

\subsubsection{Summary of Maximum Likely Doses}

Table 4.11 provides the maximum likely doses to individuals from current therapeutic procedures. The estimates indicate that only the therapies and a few diagnostic procedures involving radioiodine would be affected by any of the alternatives under consideration.

\subsubsection{Collective Dose}

To evaluate each alternative, it is also necessary to estimate not only the dose to the maximally exposed individual, but also the collective dose to other individuals who may be exposed to patients administered radioactive materials. To calculate precisely the collective dose that would be received under any of the alternatives would require detailed information of a highly diverse group of patients relative to lifestyles, living arrangements, work environments, social activities, etc. This information does not exist and is essentially impossible to precisely determine. In place of a precise estimate we have made a rough estimate of the collective dose per procedure which we believe is adequate for the purposes of this rulemaking.

Based on considerations of the written instructions provided patients, the demographics of the patient population (see Table 4.3), and time, distance, and shielding factors, we estimate that the collective dose per procedure is 3 times the maximal dose. This 3 times factor could occur in the following manner, based upon intuitive assumptions about a typical family and friends. In addition to the person receiving the maximal dose, who is likely to be the primary care-provider, there could be 2 other people who will average about half as much time near the patient. There might also be about 4 other people who will average about a quarter as much time near the patient as the maximally exposed individual. The sum of the collective dose to all these people is 3 times the dose to the maximally exposed individual. This situation could represent a typical family and friends. Of course some patients will spend more time near other people, but other patients will spend less. A collective dose of 3 times the dose to the maximally exposed 
Table 4.11 Maximum Likely Doses to Exposed Individuals from Therapeutic Procedures

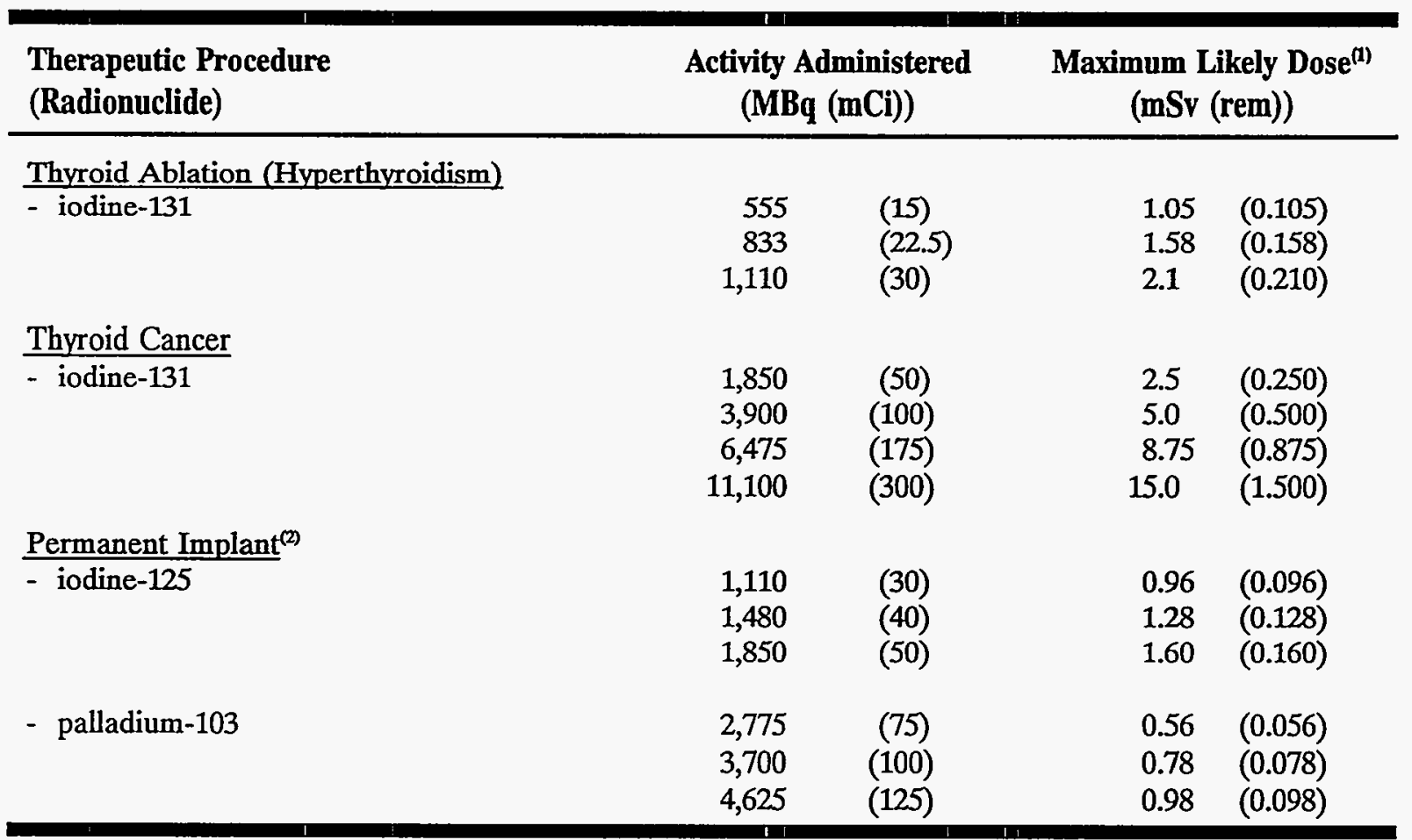

(1) For iodine-125, time-integrated activities and cumulative doses are calculated for a 1-year period, which represents 98.5 percent of the dose-to-total decay.

(2) These values account for the 5 HVLs of tissue shielding by the patient and, therefore, are equal to the point source dose in air divided by 32 .

individual is thus a reasonable average representation.

Finally, as data are not available on the distribution of the quantities of radionuclides administered for each procedure, the estimates of collective dose for each alternative are based on the mid-point values within the ranges of the activities administered.

Tables $4.12,4.13$, and 4.14 present the estimates of the collective doses for Alternatives 1,2, and 3, respectively for therapeutic administrations that could be affected by choice of alternative. Implants using palladium-103 are not included because doses to exposed individuals are always less than 1 millisievert ( $0.1 \mathrm{rem})$.

In Table 4.12, the collective dose per procedure was determined in the following manner. For all types of procedures in the table, the average activity administered will cause a dose to the most highly exposed individual that may exceed 1 millisievert $(0.1 \mathrm{rem})$. Therefore it was assumed that all patients would remain hospitalized until the dose dropped to 1 millisievert (0.1 rem). Thus, the dose to the most exposed individual would be 1 millisievert $(0.1 \mathrm{rem})$. The collective dose per procedure is then assumed to be 3 times the dose to the most exposed individual. In Table 4.13, the collective dose per procedure was calculated in the following manner. For thyroid ablation, no hospitalization is required ecause the administered activity is less than 1,110 megabecquerels (30 millicuries).

From Table 4.11, the dose to the most exposed individual from an administration of 833 megabecquerels ( 22.5 millicuries) is 1.58 millisieverts ( $0.158 \mathrm{rem})$. The collective dose is 3 times the individual dose or 4.74 millisieverts $(0.474 \mathrm{rem})$. The collective dose per procedure for iodine- 125 implants was calculated in the same manner assuming no hospitalization. For thyroid cancer, hospitalization is assumed until the activity remaining in the patient's body is 1,110 megabecquerels ( 30 millicuries). The estimated annual total effective dose equivalent to the maximally exposed individuals from a patient containing 
Table 4.12 Estimates of Collective Dose from Therapeutic Radioiodine Procedures for Alternative 1: Annual Limit of 1 millisievert (0.1 rem)

\begin{tabular}{|c|c|c|c|c|c|c|c|}
\hline $\begin{array}{l}\text { Therapeutic } \\
\text { Procedure } \\
\text { Thyroid Ablati } \\
\end{array}$ & \multicolumn{2}{|c|}{$\begin{array}{l}\text { Average Activity } \\
\text { Administered } \\
\text { (MBq (mCi)) }\end{array}$} & \multicolumn{2}{|c|}{$\begin{array}{c}\text { Collective } \\
\text { Dose/Procedure } \\
(\mathrm{mSv}(\mathrm{rem}))\end{array}$} & $\begin{array}{c}\text { Estimated } \\
\text { Procedures } \\
\text { per Year }\end{array}$ & \multicolumn{2}{|c|}{$\begin{array}{c}\text { Total } \\
\text { Collective Dose } \\
\text { (person-Sv (rem)) }\end{array}$} \\
\hline - iodine-131 & 833 & $(22.5)$ & 3 & $(0.3)$ & 50,000 & 150 & $(15,000)$ \\
\hline \multicolumn{8}{|c|}{ Thyroid Cancer } \\
\hline - iodine- 131 & 6,475 & (175) & 3 & $(0.3)$ & 10,000 & 30 & $(3,000)$ \\
\hline \multicolumn{8}{|c|}{ Permanent Implant } \\
\hline - iodine-125 & 1,480 & (40) & 3 & $(0.3)$ & 2,000 & 6 & $(600)$ \\
\hline All Therapeu & & & & & 62,000 & 186 & $(18,600)$ \\
\hline
\end{tabular}

Table 4.13 Estimates of Collective Dose from Therapeutic Radioiodine Procedures for Alternative 2: Limits of 1,110 megabecquerels (30 millicuries) or 0.05 millisievert (5 millirems)/hr

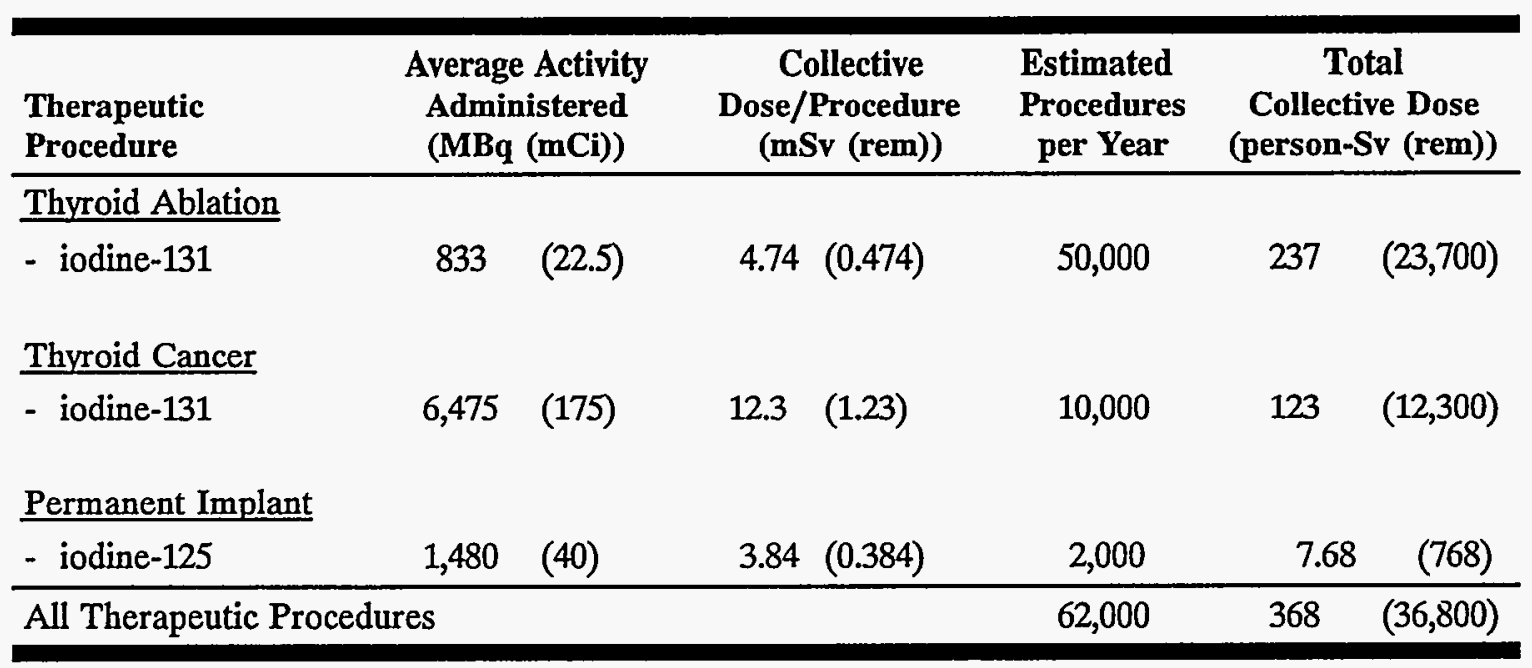


Table 4.14 Estimates of Collective Dose from Therapeutic Radioiodine Procedures for Alternative 3: Annual Limit of 5 millisieverts $(0.5 \mathrm{rem})$

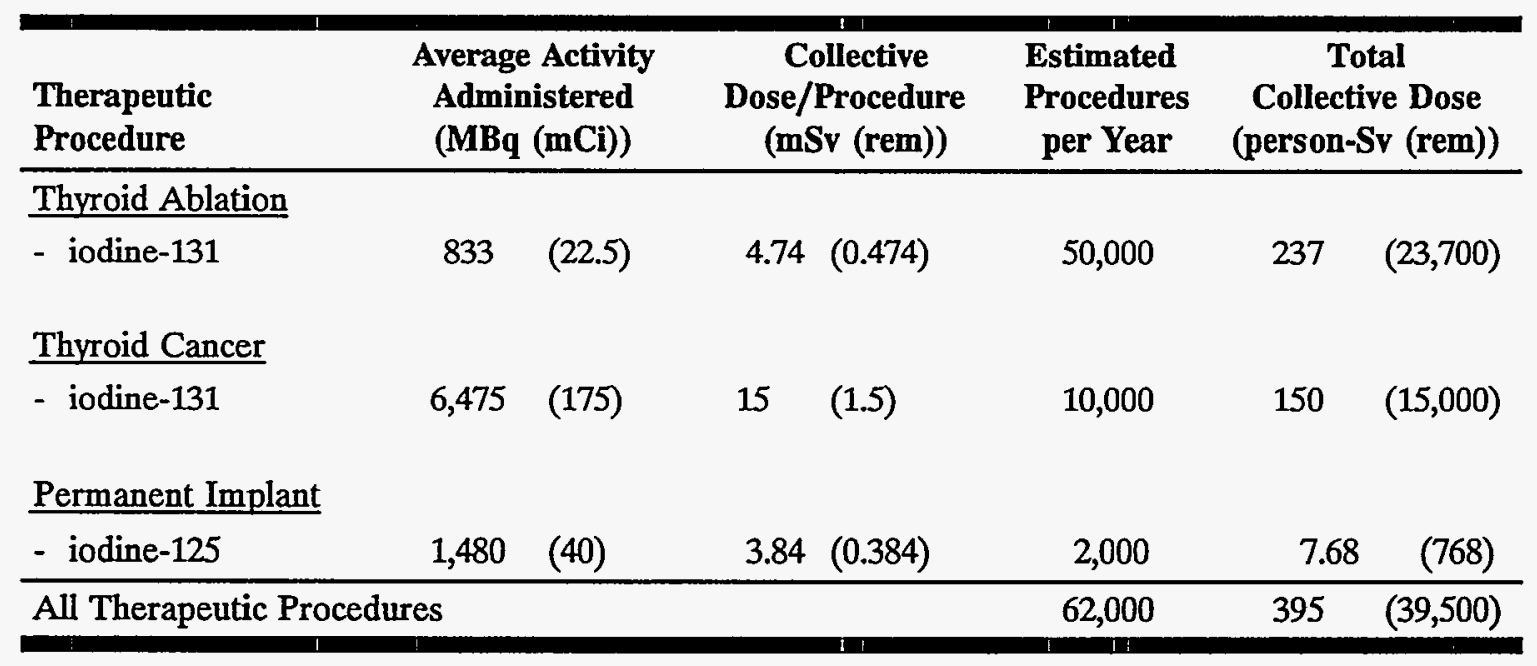

1,110 megabecquerels ( 30 millicuries) is estimated to be 4.1 millisieverts $(0.41 \mathrm{rem})$.

In Table 4.14, the collective dose per procedure for thyroid cancer is estimated by assuming hospitalization until the maximum dose to an individual would be 5 millisieverts $(0.5 \mathrm{rem})$. The collective dose is therefore 15 millisieverts (1.5 rems), using the previously described assumption that the collective dose will be 3 times the dose to the maximally exposed individual.

\subsection{Value Impact Analysis}

\subsubsection{Estimates of the Potential Costs}

The analysis in Section 4.2 indicates that the 1 millisievert $(0.1 \mathrm{rem})$ per year dose limit imposed by Alternative 1 would result in the smallest collective dose to individuals exposed to released patients. The benefit of smaller doses estimated for Alternative 1 will only be achieved if the patients to whom the radioactive materials have been administered are retained under the control of licensees for longer periods of time. The impact of retaining patients must be assessed in terms of the patient, family, and society as a whole. At a minimum, the economic cost must consider the direct cost of medical resources required to retain the patient in a hospital and the indirect cost resulting from the loss of human resources. Additional consideration should be given to the psychological impact of retention on the affected individual and family members. Hospitalization will also cause an increase in the dose to the hospital staff and other patients in the hospital. However, the increase in dose to the hospital staff is expected to be low relative to a patient going home earlier because of the precautions taken during hospitalization; e.g., patients are isolated and the hospital staff rarely enters the patient's room.

In the analysis that follows, these costs are calculated assuming that all retained patients will be hospitalized. While retention costs might be less for non-hospital locations, no attempt is made in this analysis to quantify the potential costs.

\subsubsection{Estimates of the Direct Costs of Patient Retention}

\section{Durations of Patient Retention}

Estimates of the periods of time that patients would need to be retained under licensee control for each of the alternatives are presented in Table 4.15. These estimates are based on the limits imposed by each alternative and employ the midpoint activities used for a given medical procedure.

\section{Cost of Patient Retention}

To estimate the annual dollar costs for these periods of retention, one needs only multiply the 
Table 4.15 Duration of Retention per Therapeutic Procedure (to the nearest day)

\begin{tabular}{|c|c|c|c|c|c|c|c|}
\hline $\begin{array}{l}\text { Therapeutic } \\
\text { Procedure }\end{array}$ & $\begin{array}{c}\text { Midpoint } \\
\text { Activity } \\
\text { Administered } \\
\text { (MBq (mCi)) }\end{array}$ & $\begin{array}{c}\text { per } \\
\text { procedure }\end{array}$ & $\begin{array}{c}\Sigma \\
\text { procedures } \\
(\mathbf{x} 1000)\end{array}$ & $\underset{\text { procedure }}{\text { per }}$ & $\begin{array}{l}\text { ative } 2 \\
\text { ys) } \\
\qquad \Sigma \\
\text { procedures } \\
(\times 1000)\end{array}$ & $\begin{array}{r}\text { Altern } \\
\text { (d) } \\
\text { per } \\
\text { procedure }\end{array}$ & $\begin{array}{l}\text { ative } 3 \\
\text { ys) } \\
\qquad \Sigma \\
\text { procedures } \\
(x \text { 1000) }\end{array}$ \\
\hline \multicolumn{8}{|c|}{$\begin{array}{l}\text { Thyroid Ablation } \\
\text { I- } 131,50,000 \\
\text { procedures/year }\end{array}$} \\
\hline \multicolumn{8}{|c|}{$\begin{array}{l}\text { Thyroid Cancer } \\
\text { I-131, 10,000 } \\
\text { procedures/year }\end{array}$} \\
\hline & $6,475 \quad(175)$ & 21 & 210 & 6 & 60 & 3 & 30 \\
\hline \multicolumn{8}{|c|}{$\begin{array}{l}\text { Permanent Implant, } \\
\text { I-125, } 2,000 \\
\text { procedures/year }\end{array}$} \\
\hline & 1,480 & 21 & 42 & 0 & 0 & 0 & 0 \\
\hline $\begin{array}{l}\text { Total for Al } \\
\text { Procedures }\end{array}$ & herapeutic & & 402 & & 60 & & 30 \\
\hline
\end{tabular}


number days required for each procedure by the number of procedures per year and the average cost per day of hospitalization. In 1990, the average cost per day in a community hospital was $\$ 687$ (SA92). Based on an 8 percent per year increase (SA92), the per diem cost at the beginning of 1993 would be estimated to be $\$ 800$. However, as the current regulations require that patients who are hospitalized from a therapeutic administration of radiopharmaceuticals to be placed in a private room, the $\$ 800$ per day estimate is adjusted to $\$ 1,000$ per day. Using this figure, the potential costs of retaining patients under Alternative 1 are estimated to be $\$ 402$ million. Under Alternative 2, the estimated cost is $\$ 60$ million. And, under Alternative 3, the estimated cost is $\$ 30$ million.

\section{Costs of Providing Recordkeeping}

The currently envisioned proposed rule associated with Alternative 3 imposes additional paperwork and recordkeeping requirements on the estimated 1,350 licensees (NRC- and Agreement State-

licensed) that provide therapeutic administrations of radiopharmaceuticals or permanent radioactive implants. For therapeutic administrations where the annual dose to an exposed individual could exceed 1 millisievert $(0.1 \mathrm{rem})$ total effective dose equivalent, licensees would be required to record the estimate of maximum annual total effective dose equivalent that is likely to be received by an individual, and to retain the record for three years.

It is estimated that approximately 62,000 therapeutic procedures per year would be subject to these requirements. A cost of $\$ 33$ per patient is estimated. This results in an annual estimated cost of approximately $\$ 2.1$ million.

\subsubsection{Derivation of Indirect Costs}

\section{Loss of Time}

Indirect costs principally reflect the time and output lost or forfeited by the patient while retained in a controlled environment. Indirect costs may also be incurred by individuals other than the patient who may forego economic activities to accommodate a family member's hospital retention. Economic activities include occupational work that is lost to either the patient or his or her employer as well as non-occupation- al (e.g., domestic) work which must be performed by someone else at the expense of the patient.

The conversion of time lost from economic activities to equivalent dollars is most fairly achieved by means of the gross national product (GNP). The GNP is considered the most comprehensive measure of the country's economic activity and includes the market value of all goods and services that have been bought for final use during a year. From the GNP of about $\$ 5,600$ billion in 1991 , the gross average annual per capita income of about $\$ 22,000$ is derived. The value of $\$ 22,000$ per year corresponds to $\$ 60$ per day and can be used to determine the equivalent dollar value for the number of days lost due to retention of an individual. The value of the days lost is shown in Table 4.16.

\subsubsection{Evaluation of Psychological Costs}

Retention of patients in a hospital by design necessitates that the patient be "isolated" and that human contact, inclusive of family members, is either avoided or minimized. Such isolation may bring about numerous changes and impositions in the lives of the patient and family members that may in part be linked to, but are not reflected in, the direct and indirect economic costs identified above. The wide variety of deterioration in the quality of life brought on by illness are frequently referred to as psychological costs. For thyroid cancer or dysfunction requiring therapeutic doses of iodine-131 for example, a deterioration in the quality of life may be precipitated by the loss of bodily function, a lifetime dependence on medication, hormonal instability, uncertainty of normal life-expectancy, disruption of normal daily routines, and reduced financial security related to employment, lost earnings, and medical expenses.

While some of these elements of psychological costs are the result of the disease itself, others such as disruption of normal routines, social isolation, and enhanced financial strain are clearly elements of psychological costs that are directly related to patient retention. In characterizing psychological costs, Thomas Hodgson (HO84) chief economist for the Department of Health and Human Services' Offices of Analysis and Epidemiology states: ". . . The environment created by illness often induces anxiety, reduced self-esteem and feelings of well-being, resentment, and emotional problems that often require 
Table 4.16 Costs of Alternatives 1, 2, and 3

\begin{tabular}{|c|c|c|c|c|c|c|}
\hline \multirow[b]{2}{*}{ Alternative } & \multirow[b]{2}{*}{$\begin{array}{c}\text { Collective Dose } \\
\text { (person-rem) }\end{array}$} & \multirow[b]{2}{*}{$\begin{array}{c}\text { Hospital } \\
\text { Retention } \\
\text { (days) }\end{array}$} & \multicolumn{4}{|c|}{ Cost Estimates } \\
\hline & & & $\begin{array}{c}\text { Hospitalization } \\
\text { cost } \\
\$ \\
\text { (millions) }\end{array}$ & $\begin{array}{c}\text { Value of } \\
\text { lost time } \\
\$ \\
\text { (millions) }\end{array}$ & $\begin{array}{c}\text { Record } \\
\text { keeping } \\
\$ \\
\text { (millions) }\end{array}$ & $\begin{array}{c}\text { Psychological } \\
\text { cost } \\
\text { (relative) }\end{array}$ \\
\hline 1 & 18,600 & 402,000 & 402 & 24.1 & 0 & High \\
\hline 2 & 36,800 & 60,000 & 60 & 3.6 & 0 & Moderate \\
\hline 3 & 39,500 & 30,000 & 30 & 1.8 & 1.2 & Low \\
\hline
\end{tabular}

psychotherapy. Problems of living arrangements may develop, leading to family conflict, antisocial behavior and suicide. ... The combination of financial strain and psychological problems can be especially devastating."

\subsubsection{Cost Comparison of Alternatives}

Table 4.16 summarizes the most relevant data pertaining to the costs of the three alternatives under consideration. Quantitative values are based on the midpoint activity values of iodine-131 used in the therapeutic treatments of hyperthyroidism and thyroid neoplasms and iodine- 125 seeds which are used in permanent implants for treatment of select solid tumors. Due to the subjective nature of psychological costs, comparison is provided on a relative scale.

\subsection{Evaluation of The Alternatives With Respect To Accepted Radiation Protection Principles}

Selection of the 5-millisieverts (0.5-rem) total effective dose equivalent per year criterion is consistent with: the Commission's provision in 10 CFR 20.1301(c) for authorizing a licensee to operate up to this limit; the recommendations of the International Commission on Radiological Protection (ICRP) in ICRP Publication 60, "1990 Recommendations of the International Commission on Radiological Protection;" and the recommendations of the NCRP in NCRP Report No. 116, "Limitation of Exposure to Ionizing Radiation." Each of these provide a basis for allowing individuals to receive annual doses up to 5 millisieverts ( $0.5 \mathrm{rem})$ under certain circumstances. Both ICRP and NCRP recommend that an individual be allowed to receive a dose up to 5 millisieverts $(0.5 \mathrm{rem})$ in a given year in temporary situations where exposure to radiation is not expected to result in doses above 1 millisievert $(0.1 \mathrm{rem})$ for long periods of time. The recommendations of the ICRP and NCRP are based on their finding that annual doses in excess of 1 millisievert $(0.1 \mathrm{rem})$ to a small group of people, provided that they do not occur often to the same group, need not be regarded as especially hazardous. Although the risk is potentially greater under Alternative 3, it is still within the range of acceptable risk for radiation exposure accepted by the NRC (as implemented under the revised 10 CFR Part 20).

\section{DECISION RATIONALE}

1. All of the Alternatives are acceptable according to generally accepted radiation protection principles, as those expressed by NRC, NCRP, and ICRP, as discussed in Section 4.4.

2. Alternative 1 is considerably more expensive to the public compared to Alternative 2 (the status quo) or Alternative 3. Even neglecting the psychological costs, which have not been expressed in dollar terms, the incremental cost of Alternative 1 relative to Alternative 2 is about $\$ 363,000,000$ per year, mostly in increased national health care costs. The 
value of the dose savings at a value of $\$ 1,000$ per person rem is $\$ 18,200,000$ per year. In view of this, Alternative 1 may be dismissed.

3. Alternative 3 relative to Alternative 2 has a value of $\$ 30,600,000$ per year, mostly in lower health care costs at a collective dose cost of $\$ 2,700,000$ per year. Alternative 3 also has psychological benefits to patients and their families. Thus, Alternative 3 is cost effective in comparison with Alternative 2.

4. Basing the patient release criteria in 10 CFR 35.75 on the dose to individuals exposed to a patient provides a consistent, scientific basis for such decisions that treats all radionuclides on a risk-equivalent basis. The dose delivered by an initial activity of 30 millicuries or a dose rate at 1 meter of 5 millirems per hour varies greatly from one radionuclide to another. Thus, while the values in the current 10 CFR 35.75 may be appropriate for iodine-131, they are too high for some other radionuclides and too low for others. A dose-based rule, such as Alternative 3, provides a consistent approach for regulating new therapies, such as radiolabelled antibodies, as was discussed in Section 4.1.2.1.

5. A dose-based rule no longer restricts patient release to a specific activity, and therefore would permit the release of patients with activities that are greater than currently allowed. This is especially true when casespecific factors are evaluated to more accurately assess the dose to other individuals. As can be seen in Table 4.11 for the case of thyroid cancer, in those cases where multiple administrations in a year of 1,110 millisieverts (30 millicuries) or less of iodine-131 are now administered to a patient, it may be possible to give all of the activity in a single administration. This would reduce the potential for repeated exposures to hospital staff and to those providing care to the released patient.

Additionally, this would provide physicians with the flexibility to not have to fractionate doses to avoid hospitalization to meet the current requirements, which may lead to a more effective treatment.

6. Shorter hospital stays provide emotional benefits to patients and their families. Allowing earlier reunion of families can improve the patient's state-of-mind, which in itself may improve the outcome of the treatment and lead to the delivery of more effective health care.

\section{IMPLEMENTATION}

No impediments to implementation of the recommended alternative have been identified. The staff is preparing a Regulatory Guide for licensees which will provide, in part, simple methods to evaluate the dose to the individual member of the public likely to receive the highest dose from the released patient. This will enable licensees to determine when a patient may be released from their control. 


\section{REFERENCES}

ACR75 American College of Radiology, 1975, "Survey on Regionalization in Nuclear Medicine," Washington, DC.

ACR82 American College of Radiology, 1982, "Manpower III: A Report of the ACR Committee on Manpower," Chicago, IL.

ACS93 American Cancer Society, "Cancer Facts \& Figures - 1992," Atlanta, GA.

AG92 Agbi, C.B., M. Bernstein, N. Laperriere, P. Leung, M. Lumley, 1992, "Patterns of Recurrence of Malignant Astrocytoma following Stereotactic Interstitial Brachytherapy with Iodine-125 Implants," Int. J. Radiat. Oncol. Biol. Phys. 23(2):321.

BL87 Blake, G.M., M.A. Zivanovic, A.J. McEwan, B.R. Condon, D.M. Ackery, 1987, "Strontium-89 Therapy: Strontium Kinetics and Dosimetry in Two Patients Treated for Metastasizing Osteosarcoma," Br. J. Radiol. 60:253.

BL88 Blake, G.M., M.A. Zivanovic, R.M. Blaquiere, D.R. Fine, A.J. McEwan, D.M. Ackery, 1988, "Strontium-89 Therapy: Measurement of Absorbed Dose to Skeletal Metastases," J. Nucl. Med. 29:549.

BL71 Blum, M., R. Chandra, and C.H. Marshall, 1971, "Environmental Contamination with 131-iodine Related to the Treatment of Hyperthyroidism and Carcinoma of the Thyroid Gland," IEEE Trans. Nucl. Sci., Ns-18(1):57.

BU70 Buchanan R.C.T. and J.M. Brindle, 1970, "Radioiodine Therapy to Outpatients - The Contamination Hazard," Br. J. Radiology 43:479.
CA88

Carey, P.O., M.C. Lippert, W.C. Constable, D. Jones, B.M. Talton, 1988, "Combined Gold Seed Implantation and External Radiotherapy for Stage-B2 or C Prostate Cancer," J. Urol. 139:989.

CA87 Carlton, C.E., P.T. Scardino, 1987, "Combined Interstitial and External Irradiation for Prostatic Cancer," Prog. Clin. Biol. Res. 243B:141.

CH80 Cheung, A., A.A. Driedger, 1980, "Evaluation of Radioactive Phosphorus in the Palliation of Metastatic Bone Lesions from Carcinoma of the Breast and Prostate," Radiology 134:209.

CL89

CO87

DE86

Clarke, D.H., G.K. Edmundson, A. Martinez, R.C. Matter, F. Vicini, E. Sebastian, 1989, "The Clinical Advantages of $\mathrm{I}-125$ Seeds as a Substitute for Ir-192 Seeds in Temporary Plastic Tube Implants," Int. J. Radiat. Oncol. Biol. Phys. 17(4):859.

Cobb, L.M., S.A. Butler, 1987, "Treatment of the Murine Lymphoma A31 with Intravenous, Sterilized ${ }^{114 m}$ In-loaded A31 Cells," Radiother Oncol. 10:217.

Delaney, T.F., W.U. Shipley, M.P. O’Leary, P.J. Biggs, G.R. Prout, Jr., 1986, "Preoperative Irradiation Lymphadenectomy and I-125 Implantation for Patient with Localized Carcinoma of the Prostate," Int. J. Radiat. Oncol. Biol. Phys. 12:1779

DG79 DeGroot, LJ., 1979, "The Thyroid," In: Textbook of Medicine, P.B. Beeson, W. McDermott, J.B. Wyngaarden, Eds., W.B. Saunders Company, Philadelphia, PA. 
DU81 Dunning, D.E., G. Schwarz, 1981, "Variability of Human Thyroid Characteristics and Estimates of Dose from Ingested I-131," Health Physics 40:661.

EH87 Ehrhardt, G.J., D.E. Day, 1987, "Therapeutic Use of Y-90 Microspheres," Nucl. Med. Biol. 14:233.

FDA85 Food and Drug Administration, "Radiation Experience Data (RED), 1980, Survey of U.S. Hospitals," Department of Health, Education and Welfare, Publication FDA 868253.

FI89 Finkler, N.J., A.I. Kassis, M.G. Muto, K. Weadock, S.S. Tumeh, V.R. Zurawski, Jr., R.C. Knapp, 1989, "Intraperitoneal Radioiodinated OC 125 in Patients with Advanced Ovarian Cancer: Phase I Study," J. Nucl. Med. 30:904.

FL92 Fleischman, E.H., A.R. Kagan, O.E. Streeter, J. Tyrell, M. Wollin, C.A. Leagre, J.C. Harvey, 1992, "Iodine125 Interstitial Brachytherapy in the Treatment of Carcinoma of the Lung," J. Surg. Oncol. 49(1):25.

FR88 Fritjofsson, A., D.J. Cederlund, B.J. Norlen, H. Wicklund, 1988, "Combined Therapy with Interstitial Gold Implantation and External Irradiation in the Management of Prostate Cancer," Scand. J. Urol. Nephrol. Suppl. 110:117.

FU91 Fuks, A., S.A. Lerbel, K.E. Wallner, C.B. Begg, W.R. Fair, L.L. Anderson, 1991, "The Effect of Local Control on Metastatic Carcinoma of the Prostate: Long Term Results in Patients Treated with I125," Int. J. Radiat. Oncol. Biol. Phys. 21:537.

HA74 Harbert, J.C. and S. N. Wells, 1974, "Radiation Exposure to the Family of Radioactive Patients," J. Nuclear Medicine 15(10):887.
Herba, M.J., F.F. Illescas, M.P. Thirlwell, G.J. Boos, L. Rosenthall, M. Atri, P.M. Bret, 1988, "Hepatic Malignancies: Improved Treatment with Intraarterial Y-90," Radiology 169:311.

HE82

$\mathrm{HO} 84$

HO91

HO84

ICRP79

JA81

JA78 Toeroek, 1978, "Contamination of the Home Environment by Patients Treated with Iodine-131," Am. J. Public Health 68(3):225. 
JO83

Johnson, J.L., D.L. Abernathy, 1983, "Diagnostic Imaging Procedure Volume in the U.S.," Radiology 146:851.

KA81

KE87

KL87

KO75

LA90

LE85

LO56
Kaplan, W.D., R.E. Zimmerman, W.D. Bloomer, R.C. Knapp, S.J. Adelstein, 1981, "Therapeutic Intraperitoneal P-32: A Clinical Assessment of the Dynamics of Distribution," Radiology 138:683.

Ketring, A.R., 1987, " ${ }^{1153}$ Sm-EDTMP and ${ }^{186}$ Re-HEDP as Bone Therapeutic Radiopharmaceuticals," Nucl. Med. Biol., 14:223.

Kloiber, R., C.P. Molnar, M. Barnes, 1987, "Sr-39 Therapy for Metastatic Bone Disease: Scintigraphic and Radiographic Follow Up," Radiology 163:719.

Kohler, G. and C. Milstein, 1975, "Continuous Cultures of Fused Cells Secreting Antibody of Predefined Specificity," Nature 256:495.

Lattimer, J.C., L.A. Corwin, J. Stapleton, W.A. Volkert, G.J. Ehrhardt, A.R. Ketring, S.K. Anderson, J. Simon, W.F. Goeckeler, 1990, "Clinical and Clinicopathologic Response of Anine Bone Tumor Patients to Treatment with Samarium-153-EDTMP," J. Nucl. Med. 31:1316.

Lenhard, R.E., S.E. Order, J.J. Spunberg, S.O. Asbell, S.S. Leibel, 1985, "Isotopic Immunoglobulin: A New Systemic Therapy for Advanced Hodgkin's Disease," J. Clin. Oncol. 3:1296.

Loevinger, R., E.M. Japha, G.L. Brownell, 1956, "Discrete Radioisotope Sources," In: Radiation Dosimetry, G.J. Hine, G.L. Brownell, Eds., Academic Press, Inc., New York
Marshall C.H., R. Chandra, and M. Blum, 1973, "Contamination of Air and Surroundings by Patients Treated with Large Quantities of Iodine-131 for Thyroid Carcinoma," CONF-730907 Part II, W.S. Snyder, Ed., 1169.

MA78 Martini, N., A.H. Freiman, R.C. Watson, B.S. Hilaris, 1978, "Intrapericardial Instillation of Radioactive Chromic Phosphate in Malignant Pericardial Effusion," AJR 128:639.

MA88 Maxon, H.R., E.A. Deutsch, S.R. Thomas, K. Libson, S.J. Lukes, C.C. Williams, S. Ali, 1988, "Re-186(Sn) HEDP for Treatment of Multiple Metastatic Foci in Bone: Human Distribution and Dosimetric Studies," Radiology 166:501.

ME90

ME85

ME86

Meigooni, A.S., S. Sabnis, R. Nath, 1990, "Dosimetry of Palladium-103 Brachytherapy Sources for Permanent Implants," Endocurietherapy Hyperthermia Oncology 6:107.

Mettler, F.A. Jr., A.G. Williams, J.H. Christie, R.D. Moseley, C.A. Kelsey, 1985, "Trends and Utilization of Nuclear Medicine in the U.S.: 1972 - 1982," J. Nucl. Med 26:201.

Mettler, F.A. Jr., J.H. Christie, A.G. Williams, R.D. Moseley, C.A. Kelsey, 1986, "Population Characteristics and Absorbed Dose to the Population from Nuclear Medicine: U.S. - 1982," Health Physics 50(5):619.

MO65 Modan, B., A.M. Lilienfeld, 1965, "Polycythemia Vera and Leukemia The Role of Radiation Treatment," Medicine 44:305.

MO92 Mohiuddin, M., F. Rosato, D. Barbot, A. Schuricht, W. Biermann, R. Cantor, 1992, "Long-term Results of Combined Modality Treatment with I-125 Implantation for Carcinoma of the Pancreas," Int. J. Radiat. Oncol. Biol. Phys. 23(2):305. 
MO88

Morton, J.D., R.E. Peschel, 1988, "Iodine-125 Implants versus External Beam Therapy for Stage-A2, B and C Prostate Cancer," Int. J. Radiat. Oncol. Biol. Phys. 14:1153.

NCRP70 National Council on Radiation Protection and Measurements, 1970 "Precautions in the Management of Patients who have Received Therapeutic Amounts of Radionuclides," NCRP Report No. 37, Washington, DC.

NE90 Nelp, W.B., J.F. Eary, O.W. Press, C.C. Badger, P.J. Martin, F.R. Appelbaum, D. Fisher, B. Porter, I.E. Bernstein, 1990, "Clinical Response and Toxicity Following High Dose I-131 Antibody Treatment of Lymphoma," European Journal of Nuclear Medicine 16:S124.

NI80 Nishizawa, K., K. Ohara, M. Ohshima, H. Maekoshi, T. Orito, T. Watanabe, 1980, "Monitoring of I Excretions and Used Materials of Patients Treated with I-131," Health Physics 38(4):467.

OR85 Order, S.E., G.B. Stillwagon, J.L. Klein, P.K. Leichner, S.S. Siegelman, E.K. Fischman, D.S. Ettinger, T. Haulk, K. Kopher, K. Finney, M. Surdyke, S. Sels, S. Leibel, 1985, "Iodine-131 Antiferritine, A New Treatment Modality in Hepatoma: A Radiation Therapy Oncology Group Study," J. Clin. Oncol. 3:1573.

OS92 Ostertag, C.B., F.W. Kreth, 1992, "Iodine-125 Interstitial Irradiation for Cerebral Gliomas," Acta Neurochi (Austria) 119(1-4):53, Freiburg University, Federal Republic of Germany.
Park, C.H., J.H. Suh, H.S. Yoo, J.T. Lee, D.I. Kim, B.S. Kim, 1987, "Treatment of Hepatocellular Carcinoma (HCC) with Radiolabeled Lipiodol: A Preliminary Report," Nucl. Med. Commun. 8:1075.

PA84

PA11

PE42

PE86

PO90

PO93

PR92

Priestly, J.B. Jr., D.C. Beyer, 1992, "Guided Brachytherapy for Treatment of Confined Prostate Cancer," Urology 40(1):27. 
Pharmacokinetic, Biologic and Dosimetric Problems," In: Schmidt HAE, Chambron J., Eds., Nuclear Medicine - Quantitative Analysis in Imaging and Function. Schattauer, Stuttgart, 586.

RO77 Roberts, D.J., 1977, ${ }^{132}$ P-sodium Phosphate Treatment of Metastatic Malignant Disease," Clin. Nucl. Med. 2:64.

RO87 Robinson, R.G., J.A. Spicer, D.F. Preston, A.V. Wegst, N.L. Martin, 1987, "Treatment of Metastatic Bone Pain with Strontium-89," Nucl. Med. Biol. 14:219.

ROE90 Roesler, H., J. Triller, L. Geiger, H.U. Baer, H.F. Beer, L. Blumgart, 1990, Superselective 90Y-resin Embolization Therapy of Solid Tumors," European Journal of Nuclear Medicine 16:439.

RU92 Rustig, S.N., S.S. Hahn, 1992, "Advantages of using High Activity I125 Séeds in Temporary Interstitial Breast Implants," Med. Dosim. 17(4):217.

SA92 Statistical Abstracts of the U.S., 1992, U.S. Department of Commerce, Washington, DC.

SC92 Scharfen, C.O., P.K. Sneed, W.M. Wara, D.A. Larson, T.L. Phillips, M.D. Prados, K.A. Weaver, M. Malec, P. Acord, K.R. Lamborn, 1992, "High Activity Iodine-125 Interstitial Implant for Gliomas," Int. J. Radiat. Oncol. Biol. Phys. 24(4):583.

Schroder, L.E., H.R. Maxon, 1990, "Re-186-HEDP Palliation of Painful Skeletal Metastases," presented at the European Association of Nuclear Medicine Congress, Amsterdam.

(1985, "Strontium-89 Therapy for the Pain of Osseous Metastases," J. Nucl. Med. 26:345.

ST88 Stanbury, J.B., 1988, "The Physiological Basis for Blockade of Radioiodine Retention by Iodine," in Iodine Prophylaxis following Nuclear Accidents, Proceedings of a Joint WHO/CEC Workshop, E. Rubery and E. Smales, Eds., Pergamon Press, NY.

Turner, J.H., P.G. Claringbold, E.L. Hetherington, P. Dorby, A.A. Martindale, 1989, "A Phase I Study of Samarium-153 Ethylenediaminetetramethylene Phosphonate Therapy for Disseminated Skeletal Metastases," J. Clin. Oncol. 7:1926.

Verbruggen, A.M., 1990, "Radiopharmaceuticals: State of the Art," European Journal of Nuclear Medicine 17:346.

Whitmore, W.F., 1988, "Interstitial Implantation of the Prostate: 10 Year Results, Brachytherapy Update, 1988," In: Proceedings of the Memorial Sloan Kettering Cancer Center Course on Brachytherapy, B. Hilaris, Ed.

Ziessman, H.A., J.H. Thrall, P.J. Yang, S.C. Walker, E.A. Cozzi, J.E. Niederhuber, J.W. Gyves, W.D. Ensminger, M.C. Tuscan, 1984, "Hepatic Arterial Perfusion Scintigraphy with Tc-99m MAA," Radiology 152:167. 
(See instructions on the reverse)

NUREG- 1492

2. TITLE AND SUBTITLE

Regulatory Analysis on Criteria for the Release of Patients

Administered Radioactive Material

Dinaft Report for Comment

3. DATE REPORT PUBLISHED

\begin{tabular}{l|l}
\hline MONTH & YEAR \\
\hline
\end{tabular}

May

4, FIN OR GRANT NUMBER

5. AUTHOR(S)

S. Schneider, S. A. McGuire, U. H. Behling*, K. Behling*,

D. Goldin*

Draft

7. PERIOD COVERED (Inclusive Dates)

8. PERFORMING ORGANIZATION - NAME AND ADDRESS (If NRC, provide Division, Office or Region, U.S. Nuclear Regulatory Commission, and mailing address; if contractor, provide name end melling address.)

Division of Regulatory Applications

Office of Nuclear Regulatory Research

US Nuclear Regulatory Commission

Washington, DC 20555-0001

*S. Cohen and Associates, Inc. 1355 Beverly Road, Suite 250 McLean, VA 22101

9. SPONSORING ORGANIZATION - NAME AND ADDRESS (If NRC, eype "Same as above"; if contractor, provide NRC Division, Office or Region, U.S. Nuclear Regulatory Commission, and mailling address.)

Division of Regulatory Applications

Office of Nuclear Regulatory Applications

US Nuclear Regulatory Commission

Washington, DC 20555-0001

10. SUPPLEMENTARY NOTES

The Nuclear Regulatory Commission (NRC) has received two petitions to amend its regulations in 10 CFR Parts 20 and 35 as they apply to doses received by members of the public exposed to patients released from a hospital after they have been administered radioactive material. While the two petitions are not identical, they both request that the NRC establish a dose limit of 5 millisieverts (0.5 rem) per year for individuals exposed to patients who have been administered radioactive materials. This Regulatory Analysis evaluates three alternatives. Alternative 1 is for the NRC to amend its patient release criteria in 10 CFR 35.75 to use the more stringent dose limit of 1 millisievert ( $0.1 \mathrm{rem}$ ) per year in 10 CFR 20.1301(a) for its patient release criteria. Alternative 2 is for the NRC to continue using the existing patient release criteria in 10 CFR 35.75 of 1,110 megabecquerels (30 millicuries) of activity or a dose rate at one meter from the patient of 0.05 millisievert ( 5 millirems) per hour. Alternative 3 is for the NRC to amend the patient release criteria in 10 CFR 35.75 to specify a dose limit of 5 millisieverts $(0.5 \mathrm{rem})$ for patient release. The evaluation demonstrates that, except for a few diagnostic procedures using iodine-131, diagnostic procedures are unaffected by the choice of alternative. Only some therapeutic administrations of radioactive material could be affected by the choice of alternative. The evaluation indicates that Alternative 1 would cause a prohibitively large increase in the national health care cost from retaining patients in a hospital longer and would cause significant personal and psychological costs to patients and their families. The choice of Alternatives 2 or 3 would affect only thyroid cancer patients treated with iodine-131. For those patients, Alternative 3 would result in less hospitalization than Alternative 2. Alternative 3 has a potential decrease in national health care cost of $\$ 30,000,000$ per year but would increase the potential collective dose from released therapy patients by about 2,700 person-rem per year, mainly to family members. Alternative 3 would also have personal and psychological benefits for the patients and their families.

10 CFR 35.75

Patient Release Criteria

Iodine-131

Therapeutic Administration

\begin{tabular}{l} 
13. AVAILABILITY STATEMENT \\
Un 7 imi ted \\
\hline 14. SECURITY CLASSIFICATION \\
(This Pagel \\
Unclas i fied \\
\hline $\begin{array}{l}\text { (This Report) } \\
\text { Unc las } \text { i fied }\end{array}$ \\
\hline 15. NUMBER OF PAGES \\
\hline
\end{tabular}

